\title{
Measuring institutional pressures in a supply chain context: scale development and testing
}

\author{
Katri Kauppi \\ Aalto University School of Business, Department of Information and Service Management, Espoo, Finland, and \\ Davide Luzzini \\ EADA Business School, Department of Marketing, Operations and Supply, Barcelona, Spain
}

\begin{abstract}
Purpose - Increasing amount of empirical research in operations and supply chain management is using institutional theory as its theoretical lens. Yet, a common scale to measure the three institutional pressures - coercive, mimetic and normative - is lacking. Many studies use proxies or a single, grouped, construct of external pressures which present methodological challenges. This study aims to present the development of multi-item scales to measure institutional pressures (in a purchasing context).

Design/methodology/approach - First, items were generated based on the theoretical construct definitions. These items were then tested through academic sorting and an international survey. The first empirical testing failed to produce reliable and valid scales, and further refinement and analysis revealed that coercive pressure splits into two separate constructs. A second q-sorting was then conducted with purchasing practitioners, followed by another survey in Italy to verify the new measurement scale for four institutional pressures.

Findings - The multimethod and multistage measurement development reveals that empirically the three institutional pressures actually turn into four pressures. The theoretical construct of coercive pressure splits into two distinct constructs: coercive market pressure and coercive regulatory pressure.

Originality/value - The results of the paper, namely, the measurement scales, are an important theoretical and methodological contribution to future empirical research. They present a much-needed measurement for these theoretical constructs increasingly used in management research.
\end{abstract}

Keywords Surveys, Purchasing, Theories, Institutional theory, Institutional pressures, Scale development, Survey research, Q-sorting

Paper type Research paper

\section{Introduction}

Institutional theory is such a dominant theory in management that some scholars say it is creaking under its own weight (Lawrence et al., 2011, p. 52). Its contributions have been invaluable and pervasive, and we are going to witness many more ramifications of institutional work. To avoid the perils of vagueness and confusion that are typical of theories so widely applied, Alvesson and Spicer (2019) renew the attention on the founding principles expressed by Meyer and Rowan (1977) and DiMaggio and Powell (1983), with particular emphasis on the need to clarify the core contructs linked to institutional theory. In this study, we are going back to the roots and examine how the fundamental constructs of institutional pressures have been used. We will work to clarify and consolidate their meaning and measures through a scale development effort in the empirical context of supply chain management (SCM).

Based on the premise that organizational structures take form in institutionalised contexts (Meyer and Rowan, 1977), institutional theory has various streams (Scott, 1987, 2008). The sociology-based stream of institutional theory stemming from the work of DiMaggio and Powell (1983) studies organizational

The current issue and full text archive of this journal is available on Emerald Insight at: https://www.emerald.com/insight/1359-8546.htm

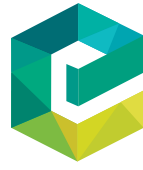

Supply Chain Management: An International Journal 27/7 (2022) 79-107

Emerald Publishing Limited [ISSN 1359-8546] [DOI 10.1108/SCM-04-2021-0169] activity from the viewpoint of legitimacy-seeking behaviour, i.e. what is acceptable in the institutional environment (Meyer and Rowan, 1977). According to this theory, organizations become isomorphic by following institutional prescriptions due to institutional pressures (Bhakoo and Choi, 2013). These pressures come in three main forms: coercive, mimetic and normative (DiMaggio and Powell, 1983).

Researchers are noting the evidence supporting institutional theory that counteracts managerial rationality (Ketokivi and Schroeder, 2004; Kauppi and Hannibal, 2017); economic explanations for organizational phenomena are incomplete (Combs et al., 2009). Increasing amount of empirical research is using this theory to explain the adoption of organizational structures, technologies, sustainability practices, quality management and human resource practices (Combs et al., 2009; Teo et al., 2003; Westphal et al., 1997; Zailani et al., 2012; Hsu et al., 2014; Huang et al., 2016; Dubey et al., 2017; Agarwal et al., 2018; Wang et al., 2018; Li et al., 2019; Venkatesh et al., 2020; Obayi and Ebrahimi, 2021). Yet,

(C) Katri Kauppi and Davide Luzzini. Published by Emerald Publishing Limited. This article is published under the Creative Commons Attribution (CC BY 4.0) licence. Anyone may reproduce, distribute, translate and create derivative works of this article (for both commercial and non-commercial purposes), subject to full attribution to the original publication and authors. The full terms of this licence may be seen at http://creativecommons.org/licences/by/4.0/legalcode

Received 27 October 2020

Revised 10 June 2021

12 August 2021

Accepted 13 August 2021 
despite the widespread empirical use, a consensus on the scales to measure the key constructs of the theory, i.e. the coercive, mimetic and normative pressures is lacking. Many past studies - across multiple fields of management - either use proxies (Honig and Karlsson, 2004; Peters and Heusinkveld, 2010; Villena and Dhanorkar, 2020), bundle all three pressures into a single construct of external pressure (Boiral and Roy, 2007; Heras-Saizarbitoria et al., 2011; Prajogo, 2011; Dubey et al., 2015; Lo and Shiah, 2016) or formulate measurement scale items where the pressures are expressed as practice (context) specific, not as independent (Ke et al., 2009; Pasamar and Alegre, 2015; Son and Benbasat, 2007; Tate et al., 2014; Adebanjo et al., 2016; Dubey et al., 2018). Each approach, however, is problematic in either providing a clear linkage with the theoretical construct (Ketokivi and Schroeder, 2004) and/ or a detailed explanation of the institutional forces at play. Thus, renewed attention is needed in operationalizing the three key constructs of institutional theory (Kauppi, 2013), i.e. coercive, mimetic and normative pressures. Only properly designed and validated measurement scales enable explanatory and predictive research and informed decision-making (Roth et al., 2008; p. 2). By continuing to use proxies, bundled "external pressure" constructs and practice-specific scales, we risk incomplete and incomparable results and are unable to demonstrate fine-grained effects of institutional pressures on managerial action. Without reliable and valid scales, testing relationships is difficult (Froehle and Roth, 2004) and without a shared set of valid and reliable scales when talking of the same constructs, a cumulative research tradition cannot exist (Moore and Benbasat, 1991).

The objective of this research is to create multi-item measurement scales to for the coercive, mimetic and normative pressure constructs to advance the cumulative tradition around the theory and make studies more comparable. We follow the two-stage approach for measurement development by Menor and Roth (2007), whereby we generate items (the individual statements forming the measurement scale), and test them in a q-sorting exercise (Moore and Benbasat, 1991) and a survey to ensure they properly reflect the constructs.

Ashill and Jobber's (2010) scale development study suggests that items should be related to the specific sub-environments studied. While we aim to develop measurement scales for various fields of management study, the development in this paper takes place within a specific organizational context, i.e. purchasing, as a part of the SCM discipline. Within SCM, institutional theory has been used to study phenomena such as the adoption of quality management practices, technological solutions and green SCM practices, but generic measurement scales for institutional pressures are lacking (Kauppi, 2013). Purchasing is seen as an ideal fit for institutional theory measurement scale development, given its boundary-spanning role towards internal and external parties (Zhang et al., 2011). The representatives of the function are likely to experience coercive pressures from external sources such as suppliers and governments, and the increasing supply chain-based competitiveness encourages the development of mimetic pressures. Furthermore, due to the increased offering of purchasing courses in universities, the managers are likely to be highly educated and increasingly subject to normative pressures. The individual item wording will thus reflect the institutional pressures experienced by the purchasing function/profession.
Suggestions are given on how to modify the items to fit other functional contexts to ensure a wider research contribution.

This paper contributes to institutional theory literature by empirically testing and validating multi-item measurement scales for the institutional pressures originally defined by DiMaggio and Powell (1983). Given the increasing number of studies addressing institutional pressures for example in the context of sustainability research (Hirschinger et al., 2016; Tachizawa et al., 2015; Mani and Gunasekaran, 2018), the operationalization of these theoretical constructs can serve the research community in future work around the theory. A detailed scale allows researchers to delve deeper into the institutional motivations driving business practices than proxy measures and grouped constructs can. In the following, a general introduction to institutional theory is provided, followed by a presentation of the pressures and the shortcomings of past measures. Then, the methodology and results for two rounds of q-sorting and surveys are presented. Finally, a discussion of results and further measurement refinement is provided, including the expected theoretical and managerial contributions of the developed scales, as well as limitations of the study.

\section{Institutional theory}

Institutional theory in this paper refers to the sociological stream of institutional theory relying primarily on the work of DiMaggio and Powell (1983). The core argument of the theory is that institutional pressures drive firms to adopt similar business practices to increase/retain their organizational legitimacy (Deephouse, 1996). DiMaggio and Powell (1983) identified three mechanisms for isomorphism:

1 coercive pressures due to political influence;

2 mimetic pressures arising from uncertainty; and

3 normative pressures linked to professionalization.

Each type of pressure is defined and discussed in detail below. The key premise of the theory in relation to the role of the three pressures is summarized in Figure 1.

\subsection{Coercive pressures}

The coercive pressure construct is defined as pressures arising from other organizations to which a firm is dependent on (e.g. critical sources, customers or governments with legislative power); they are requirements towards an organization to comply with procedures, controls and structures imposed from outside the firm (DiMaggio and Powell, 1983). Coercive pressures are requirements brought on by constituents (Liu et al., 2010), specifically by more powerful actors (Shi et al., 2008). Shi et al. (2008) divide coercive pressures into two categories: competition and regulation. The former are a result of the threat of losing competitive advantage, whereas the latter arise from government agencies and professional regulatory bodies. As organizations depend on external resources, and fear of being left out, coercive pressures drive them to adhere to expectations of the environment (Ke et al., 2009). Several sources of coercive pressures have been identified, such as resource dominant organizations (e.g. suppliers and customers), regulatory bodies, parent corporation, trading partners and investors (Jin et al., 2012; Shi et al., 2008; Son and Benbasat, 2007; Teo et al., 2003; Ugrin, 2009; 
Zsidisin et al., 2005). A powerful firm can exercise a coercive strategy to serve its own interest by demanding that partners adopt operational structures or practices (Liu et al., 2010).

\subsection{Mimetic pressures}

Mimetic pressures (also known as imitative pressures) are defined as the tendencies of firms to copy the successful actions of other firms and significant competitors when faced with uncertainty; organizations feel the need to imitate practices that are ascribed to competitors' and peers' success. Mimesis is a reaction to uncertainty. According to DiMaggio and Powell (1983) an uncertain relationship between means and ends increases the likelihood that a firm will model itself after others it perceives to be successful; it shields against the potential loss of face (Liang et al., 2007). Imitation is an attempt to economise on search costs (St John et al., 2001). Consultants may also be responsible for spreading certain organizational models (DiMaggio and Powell, 1983). Formal benchmarking and publications of effective practices contribute to this imitation (Zsidisin et al., 2005). The extensive adoption of just-in time (JIT) and total quality management (TQM), driven by benchmarking, are examples of this phenomenon (St John et al., 2001).

\subsection{Normative pressures}

Normative pressures are defined as influences arising from professionalization; they originate from professional standards and norms held in common by employees through their industry, professional associations, and education. Normative forces arise from employees belonging to trade organizations, professional associations and other networks and subscribing to explicit professional norms, such as in law and accounting (Combs et al., 2009; Ugrin, 2009). Zsidisin et al. (2005) list several validating normative institutions including colleges, universities, academic conferences and professional associations. Liang et al. (2007) suggest that within a particular industry, formal education and professional networks generate a pool of almost interchangeable employees. Members of a profession receive similar training, socializing their world views (Mizruchi and Fein, 1999). As these employees occupy comparable positions across organizations, their similar disposition overrides most variation in traditions and control mechanisms otherwise seen in organizational behavior (Liang et al., 2007). Similar professional career tracks in a field can also enhance normative pressures (DiMaggio and Powell, 1983). Also, employees and managers in industries with a lesser professional status can exchange information at trade fairs and vendor exhibitions, follow industry magazines, and use consultants to learn about best practices (Combs et al., 2009).

\subsection{Shortcomings of current measurement scales}

As noted earlier, institutional theory is increasingly used to explain the adoption of managerial practices; yet no clear and unified measurement scales for the three pressures have arisen. Appendix 1 shows a representative (though not exhaustive) sample of perceptual measures used for coercive, mimetic and normative pressures in past studies, both in operations management (OM) and SCM as well as other fields of management. According to Kauppi (2013), OM and SCM studies tend to build the measurement scales in relation to the adoption of a specific practice, indicating that pressures do not exist as separate constructs but only in relation to a specific practice being adopted. Similar problems are noted in the measures presented in Appendix 1 Yet institutional pressures to follow norms, the example of industry leaders or regulations in general are likely to exist independent of individual practices as well. The separation of dependent and independent variables in surveys either proximally or

Figure 1 Overview of the role of the three pressures in institutional theory literature

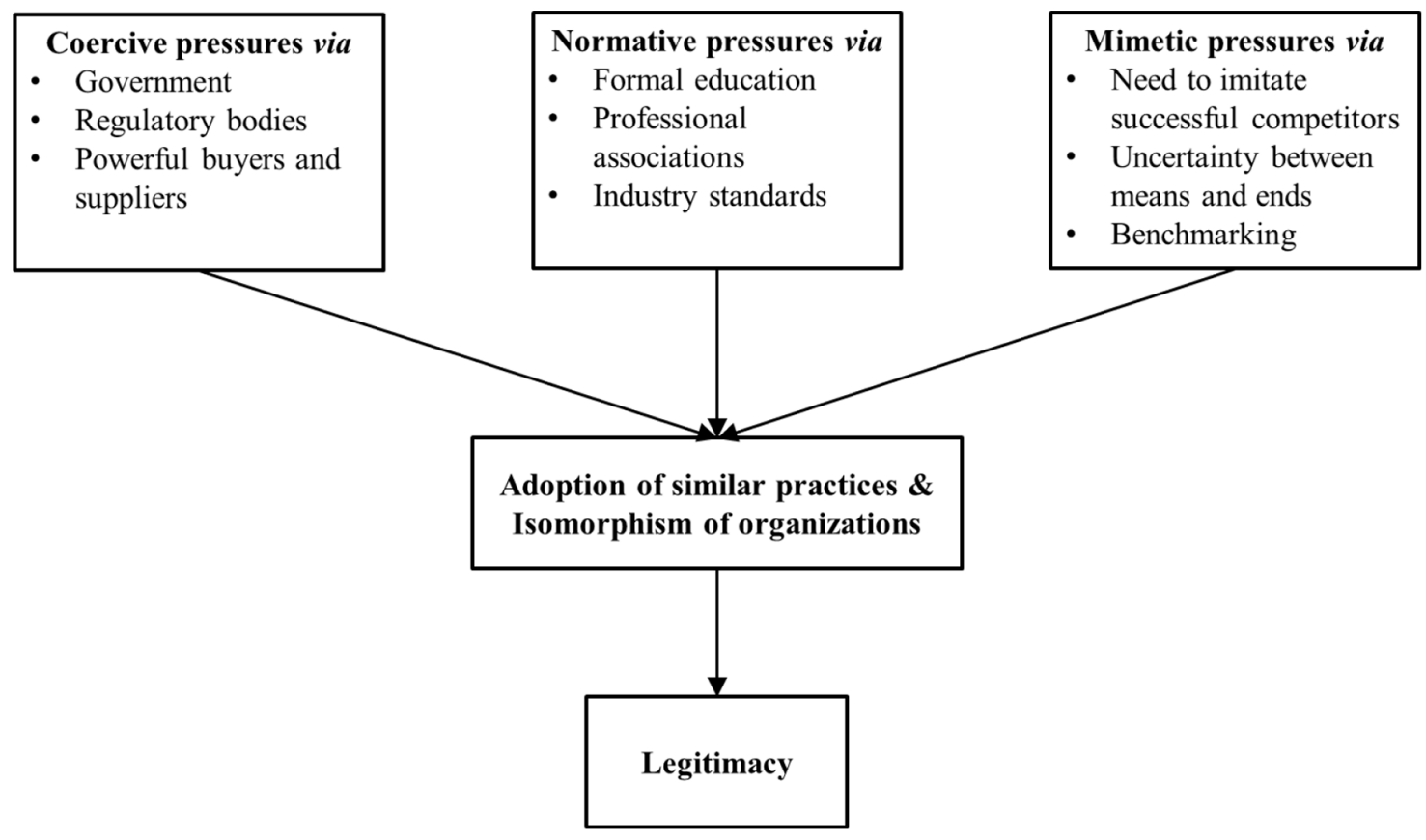


temporally is encouraged to avoid common method bias (Podsakoff et al., 2003). Thus, using items where the link between the pressure and the practice it is expected to relate is explicitly stated is problematic. Finally, Appendix 1 also shows how the scale for normative pressures often measures isomorphism as opposed to the pressure leading to it.

In addition to the perceptual measures noted in the appendix, several OM/SCM studies have used proxies (such as intensity of the tool adoption) or bundled all the three institutional pressures into one construct often termed as external pressure (Kauppi, 2013 for a brief review). Proxies tend to be problematic due to a lack of clear correspondence with a theoretical construct (Ketokivi and Schroeder, 2004). Use of proxies can contribute to misleading findings about the theory as they cannot capture the full complexity of the various dimensions of a construct (Flatten et al., 2011). Using a grouped construct of external pressure is also problematic, not allowing one to distinguish between the exact mechanisms impacting managerial action. This can ignore the variety of the different dimensions of a theoretical construct and the effects they have on firm outcomes (Flatten et al., 2011). Yet most SCM studies using institutional theory have adopted this grouping (Kauppi, 2013).

Measurement problems are present in other fields as well, according to Mizruchi and Fein (1999), who focused on the empirical treatments of DiMaggio and Powell's research. In all the articles they examined, they demonstrate that where researchers tried to operationalise mimetic isomorphism, the empirical measures used could have been interpreted as either coercive or normative isomorphism. They give an example of a measure used for mimetic effect: the percentage of firms in a particular industry that had adopted a practice. Mizruchi and Fein (1999) argue that in most empirical studies researchers are hypothesizing a particular institutional isomorphic process that results in an organizational outcome, but they capture only the outcome with their measures, and assume the process. DiMaggio and Powell (1983) themselves acknowledged that their typology of pressures is analytic, and it may be difficult to distinguish the pressures empirically. But as Mizruchi and Fein (1999, p. 680) demonstrate, incomplete operationalisations that only assume the mechanisms behind the pressures can leave research results open to reinterpretation and provide "limited and biased picture of the processes one is trying to describe". Cheng and Yu (2008) also posit that the use of secondary measures for the "ex-post" physical isomorphism rather than direct measures of "ex-ante" perceived pressures is not adequate.

\section{Methodology}

Our research approach is depicted in Figure 2, modified from Menor and Roth (2007). Specifically, due to the developed measurement scales not passing the first survey test, and one of the constructs (coercive pressure) splitting into two, we "loop back" to the "Front end" of scale development in Menor and Roth's model, and proceed with a second q-sorting and survey test to arrive at a final set of scales. Following item generation, the data collection began with a q-sorting among academics followed by testing in an international survey. As the results of the first survey did not provide a scale that would pass all statistical tests and furthermore revealed the coercive pressure construct to split into two separate constructs, we followed with a second round of data collection. Specifically, in the second stage, we conducted a q-sorting among practitioners followed by survey testing in a single country to obtain the final scale. The actual data analysis and results related to each of these steps are described in detail in the following section (Results).

\section{1 "Front end" - item generation}

We started the scale development process with item generation (Figure 2), which provides the basis for content validity (Shafiq et al., 2014). Some past studies on institutional theory have used formative constructs and some reflective ones. Baxter (2009, p. 1372) notes that "constructs are not inherently either formative or reflective"; using a sound theoretical and/or empirical reasoning allows one to use a construct both ways. Given that institutional theory suggests the three pressures to exist irrespective of the measures, we adopt a reflective model.

To establish the theoretical domain of the constructs, we searched the literature and included existing items (Rosenzweig and Roth, 2007; Zhang et al., 2014). Overall, 41 items were created for the first sorting round (Appendix 2). As items from past literature were typically worded to address a pressure for a specific practice, they were modified to reflect a general pressure for purchasing employees. New items were created for constructs with less than 10 items or where the dimensions of the construct were not seen as fully covered (Moore and Benbasat, 1991), based on past literature on the pressures and their manifestations. For example, for normative pressure construct, few items existed, yet the literature clearly acknowledges e.g. the impact of industry associations, university education and so on.

Some articles (including DiMaggio and Powell, 1983) refer to certain parties exerting different pressures simultaneously (e.g. consultants appear within mimetic and normative pressures). Therefore, if similar actors are mentioned in the items corresponding to different constructs, attention is paid to how the pressure by that actor is perceived (e.g. is it felt as a force or a leading example to encourage behaviour).

\subsection{Q-Sorting with academics}

After item generation, pretesting via the q-sort exercise aims to tentatively assess the construct validity and reliability of the developed scales and to identify potentially ambiguous items (Moore and Benbasat, 1991; Rosenzweig and Roth, 2007). We conducted four rounds of q-sorting and asked judges to sort the various items into the construct categories. Sorting procedures followed Moore and Benbasat (1991) and were done manually, i.e. each item was printed on index cards and presented to the judges in random order. Each judge was free to suggest additional items when seen necessary (Stratman and Roth, 2002) or to suggest changes to item wording. The judges could leave an item out if it was not seen to fit any of the pressures. The pressure definitions from earlier (along with brief summaries of the pressure descriptions) were provided. The first round of judges consisted of academics with previous knowledge of institutional theory. The second, third and fourth round of judges were academics in various fields of management with experience on institutional theory. 


\subsection{First "back end" - survey testing}

After the q-sorting, the developed items were empirically tested within a larger survey on purchasing strategies and practices, the International Purchasing Survey, release 2 (IPS2).

\subsubsection{Data collection}

IPS2 is a multi-country survey gathering data in four areas: general data about the organization and respondent; characteristics of the purchasing function (including institutional items); characteristics of a specific purchase category managed by the respondent; strategies, practices, and performance in this purchase category. The survey was originally developed in English (as were the institutional items) and translated to local languages using the TRAPD approach (Harkness, 2003). Piloting was carried out in each country to improve item wording, reduce survey length (as a result, 1 item from the mimetic pressures was deleted) and improve translations.

Data was collected in Finland, Germany, Ireland, and Italy, between May and December 2014. A range of manufacturing and service industries (based on ISIC codes) were included, and a random sample of companies in these industries was

Figure 2 Research process

\section{Front-end}

Specify theoretical domain and operational definition of constructs

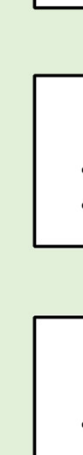

Purify and pre-test items

- Q-sort by academic judges

- Literature review

- Author experience
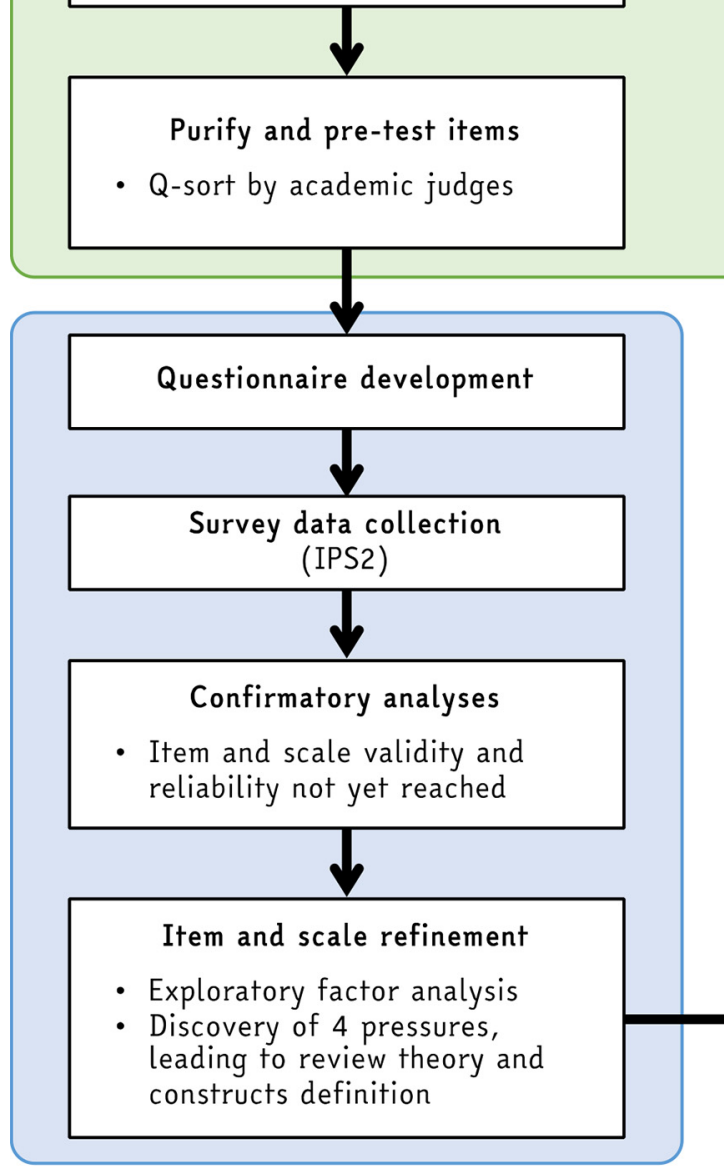

Back-end Round 1
Re-specify definitions of constructs (split of coercive pressure)

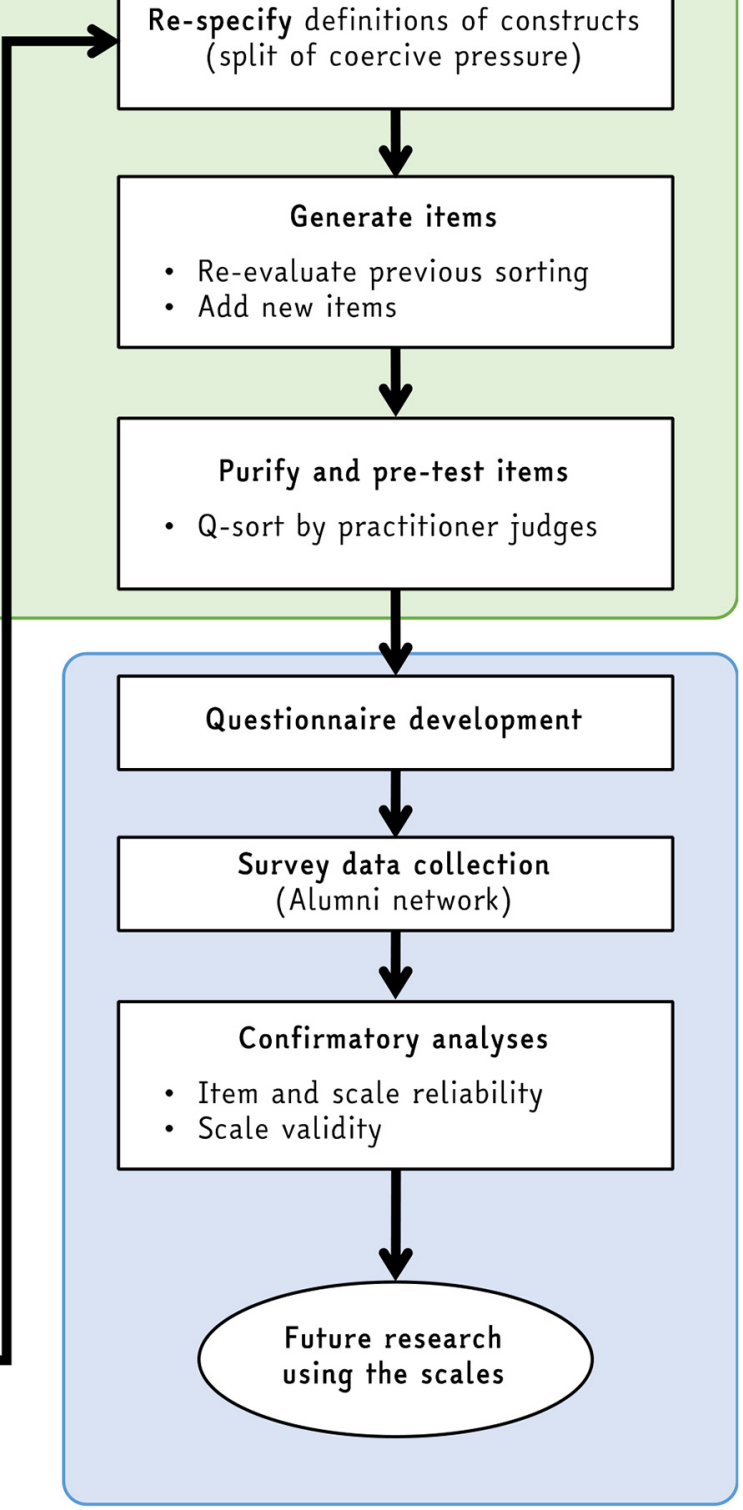

Back-end Round 2

Source: Adapted from Menor and Roth, (2007) 
drawn in each country level database (Fonecta in Finland, Dun and Bradstreet in Germany, the Bill Moss Partnership in Ireland, and AIDA in Italy). Only companies with at least 50 employees were included. All countries followed the same data collection procedures to ensure consistency. The databases across the 4 countries included a total 20,515 of companies that fit our sampling criteria. Of these, 3,068 were selected through random sampling, and 3059 were contacted (some companies were noticed after sampling to not fit the criteria, e.g. they had moved abroad or were not anymore in the industry specified), and 1,105 were reached via phone (for those not reached, either a suitable respondent was never located in the company or the suitable respondent never answered our calls). A total of 656 companies agreed to participate, and out of these 305 useable responses were received, thus yielding a $10 \%$ response rate of the total sample, and a $46 \%$ response rate of those who agreed to respond. The distribution of the above response statistics per country is provided in Appendix 3.

\subsubsection{Handling survey biases}

We accounted for potential biases through survey design and statistical control. Several approaches (direct contact by phone, multiple mailings, and the assurance to share results) were used to ensure a high response and to avoid non-response bias (Frohlich, 2002; Shafiq et al., 2014). For companies more difficult to reach, due to e.g. the purchasing department being under higher pressures to perform, a minimum of three contact attempts were made. To estimate non-response bias, we compared the descriptive statistics of the respondents to those of the random sample (Froehle and Roth, 2004) with nonparametric tests in each of the survey countries. We found no significant differences in the distribution of company size (number of employees) and industries (ISIC code). Social desirability bias in the whole IPS2 survey was reduced through e.g. assurance of confidentiality (Handley and Benton, 2012) and through asking about behaviour of the organization and its members in general rather than about direct personal behaviours (Carter, 2000).

To avoid common method bias already in the design stage, we placed questions in different sections in the questionnaire, used different scales for independent and dependent variables and included a marker variable (Lindell and Whitney, 2001; Schoenherr and Swink, 2012; Song et al., 2011). The items for institutional theory were measured on a six-point Likert scale ("extremely disagree" to "extremely agree"), while other items in the survey were measured either with a 6-point or a 7-point scale. As the current study mainly deals with the institutional items, the most relevant is the marker variable, allowing for common method variance analysis. A marker variable is expected not to be theoretically related to other variables in the survey (Lindell and Whitney, 2001). We selected two marker variables from Kauppi and van Raaij (2015) ("Our unit has very modern working facilities" and "Our unit has excellent catering facilities", on a 7-point Likert scale). A correlation analysis between the marker variables and the institutional items, and a random selection of survey items, shows neither significant nor systematic correlations.

Data cleansing took place jointly for all countries. All responses with more than $30 \%$ missing answers were discarded (already reflected in the final response). 28 out of the 305 respondents had 1 or more missing values in the institutional theory questions. These responses were deleted as any imputation method would presuppose a relationship between the different items, and this is not suitable given the goal of construct testing and development. Thus, a total of 277 responses were available with complete data on all the institutional theory items.

\subsection{Return to "front end" - a second q-sort with practitioners}

Academics were initially selected as judges for the sorting exercise given the highly theoretical nature of the items. However, given the items will eventually be used in surveys targeted for practitioners, we note the importance of using a similar audience for initial testing. Hence, we follow the convention of other scale development studies (Stratman and Roth, 2002; Menor and Roth, 2007) and use practitioners for the revised q-sorting exercise.

Two q-sorting rounds were conducted with practitioners. This time instead of printed out index cards, we used a Microsoft PowerPoint presentation where the judges moved items to different slides depending on which construct they fitted with. Also, the judges now sorted to four categories to reflect results of the first survey on the coercive pressure splitting into two. The appearance of items to the judges on the first slide was randomised.

The first sorting round consisted of 6 judges, while the second had 5 judges. All the judges were purchasing or SCM professionals in Italy. Six were from the manufacturing and five from the service sector; both rounds included judges from both sectors.

\subsection{Another "back end" - a second survey testing 3.5.1 Data collection}

We conducted the second survey using the items obtained from the practitioner q-sorting. As a further refinement of the items, we now measure them with the more common 7-point Likert scale as opposed to the 6-point Likert scale utilised in IPS2. We again included a marker variable to rule out possible common method biases. Specifically, we asked respondents to report about the state of the art of their company facilities. Again, a correlation analysis between the marker variables and the institutional items shows neither significant nor systematic correlations.

The data collection took place in one country (Italy) in 2017 through a web-based questionnaire. Prospective respondents were extracted from the alumni network of a leading business school in the country, where one of the authors is affiliated. The selection criteria were aimed at identifying the key informant i.e. a person in the company who was knowledgeable and could provide a necessary and sufficient perspective over the target concepts. We focused our attention on employees with an appropriate level of seniority whose job profiles were in the Purchasing or Supply Chain functions. The resulting sample contained 409 contacts, who were approached through personal emails explaining the research project scope as a survey about the purchasing profession and providing a link to the questionnaire. The data collection lasted from September to November and allowed for three reminders. In total, 377 respondents were reached because some e-mail addresses were 
incorrect or the person had moved to another role. 73 responses were received, of which 3 were discarded due to a high number of missing answers, leaving 70 usable responses. The response rate calculated on the initial sample of contacts is $17 \%$ (which increases to almost $19 \%$ if considering the people reached, see also Appendix 3). The respondents represent both manufacturing and service sectors (43 and 21 respondents, respectively, with 6 not providing their sector). No significant differences were found between respondents and nonrespondents in terms of the firm's industry and size.

\section{Results}

This section provides the statistical analyses and results of each round of data collection as explained in the previous section.

\subsection{Results from academic q-sorting}

Table 1 shows the judges' degree of agreement for each of the four sorting rounds. Item placement ratios indicate how many items were placed in the target category by the judges, where the suggested cut-off value is $75 \%$ (Moore and Benbasat, 1991).

In round 1 overall 17 items were deleted, many of these from previous literature. The judges commented the items actually reflected antecedent conditions leading to pressures rather than the pressures themselves. Several items in the coercive category were seen to measure dependence, while items in the mimetic category were seen to reflect uncertainty. Some items seen as a shared background were removed from the normative category. Three new items were added and two reworded. Appendix 2 provides the details of all changes and deletions for all rounds.

For the second round, most placements to non-target categories were a result of placing normative items as mimetic or vice versa. This happening in more rounds suggests that these two pressures might be closely related, and that separating them into individual constructs may pose challenges in surveys. The third round had 21 items and the ratios continued to improve apart from normative items, where some items were still placed into the mimetic category and some remained unused. The fourth and final round contained 18 items. The placement ratio was $90.35 \%$.

For each pair of judges in each sorting round, we measured their level of agreement in categorizing items using the interjudge agreement percentage and the Perreault and Leigh's measure, which capture the observed proportion of agreement between judges greater than expected by chance (Stratman and Roth, 2002). Additionally, Cohen's Kappa, a conservative estimator of interrater reliability, is used (Menor and Roth, 2007). For the Perreault and Leigh, a value of 0.65 or greater represents an acceptable level of agreement (Stratman and Roth, 2002); for the general interjudge agreement most studies do not present a cut-off. For Kappa, scores greater than 0.65 are considered acceptable (Menor and Roth, 2007). Table 2 shows a general improving trend for all measures in the consecutive rounds, apart from Cohen's K. With only 18 items to be sorted, reaching a higher Cohen's $\mathrm{K}$ is difficult, as even 1 or 2 items unused by each judge can result in a score less than 0.65 . Given that all other indicators and item placement ratios are high, and there were no further significant changes suggested, the items from the fourth round were used for survey testing.

\subsection{Results from first survey testing}

For the first survey, the respondents spread among the countries as follows: 76 from Finland, 63 from Germany, 50 from Ireland and 88 from Italy. Manufacturing companies represent 211 of the sample, 66 are service organizations. As to the respondents, 50 are CPOs or Vice presidents of purchasing, 134 Purchasing directors/Managers, 33 Senior buyers and 26 Buyers (34 others). Majority (167) have at least 11 years of purchasing experience, with 78 having 5-10years. We therefore expect the respondents to understand the institutional environment of the function. Descriptive analyses for the institutional items are in Table 3.

Table 1 Item placement ratios for all sorting rounds with academic judges

\begin{tabular}{|c|c|c|c|c|c|c|c|}
\hline & Categories & Coercive & Mimetic & Normative & Unused & Total & Ratio \% \\
\hline \multirow[t]{4}{*}{ Round 1} & Coercive & 55 & 0 & 0 & 35 & 90 & 61.11 \\
\hline & Mimetic & 1 & 46 & 10 & 27 & 84 & 54.76 \\
\hline & Normative & 12 & 7 & 41 & 12 & 72 & 56.94 \\
\hline & Total & 68 & 53 & 51 & 74 & 246 & $57.61^{\mathrm{a}}$ \\
\hline \multirow[t]{4}{*}{ Round 2} & Coercive & 52 & 5 & 1 & 2 & 60 & 86.67 \\
\hline & Mimetic & 0 & 36 & 8 & 4 & 48 & 75.00 \\
\hline & Normative & 0 & 10 & 40 & 4 & 54 & 74.07 \\
\hline & Total & 52 & 51 & 49 & 10 & 162 & $75.58^{a}$ \\
\hline \multirow[t]{4}{*}{ Round 3} & Coercive & 44 & 0 & 2 & 2 & 48 & 91.67 \\
\hline & Mimetic & 1 & 26 & 1 & 2 & 30 & 86.67 \\
\hline & Normative & 0 & 7 & 34 & 7 & 48 & 70.83 \\
\hline & Total & 45 & 33 & 37 & 11 & 126 & $83.06^{\mathrm{a}}$ \\
\hline \multirow[t]{4}{*}{ Round 4} & Coercive & 30 & 1 & 0 & 4 & 35 & 85.71 \\
\hline & Mimetic & 1 & 23 & 0 & 1 & 25 & 92.00 \\
\hline & Normative & 0 & 1 & 28 & 1 & 30 & 93.33 \\
\hline & Total & 31 & 25 & 28 & 6 & 90 & $90.35^{\mathrm{a}}$ \\
\hline
\end{tabular}

Note: ${ }^{a}$ The overall placement ratio, average of ratios for each individual construct 
Table 2 Interjudge agreement statistics for all four rounds of academic q-sorting

\begin{tabular}{|c|c|c|c|c|c|c|c|c|c|c|c|c|}
\hline \multirow{2}{*}{$\begin{array}{l}\text { Interjudge } \\
\text { combination } \mathrm{C}_{\mathrm{a} / \mathrm{b}}\end{array}$} & \multicolumn{4}{|c|}{$\begin{array}{l}\text { Interjudge agreement } \\
\text { (by sorting round) }\end{array}$} & \multicolumn{4}{|c|}{$\begin{array}{l}\text { Perreault and Leigh's } I_{r} \\
\text { (by sorting round) }\end{array}$} & \multicolumn{4}{|c|}{$\begin{array}{c}\text { Cohen's k } \\
\text { (by sorting round) }\end{array}$} \\
\hline & $1(\%)$ & $2(\%)$ & $3(\%)$ & $4(\%)$ & 1 & 2 & 3 & 4 & 1 & 2 & 3 & 4 \\
\hline$\overline{\mathrm{C} 1 / 2}$ & 78.0 & 74.1 & 76.2 & 94.4 & 0.84 & 0.81 & 0.83 & 0.96 & 0.64 & 0.63 & 0.61 & 0.74 \\
\hline $\mathrm{C} 1 / 3$ & 70.7 & 70.4 & 85.7 & 88.9 & 0.78 & 0.78 & 0.90 & 0.92 & 0.54 & 0.58 & 0.56 & 0.74 \\
\hline $\mathrm{C} 1 / 4$ & 53.7 & 85.2 & 71.4 & 83.3 & 0.62 & 0.90 & 0.79 & 0.88 & 0.30 & 0.78 & 0.59 & 0.61 \\
\hline $\mathrm{C} 1 / 5$ & 82.9 & 92.6 & 90.5 & 66.7 & 0.88 & 0.95 & 0.93 & 0.75 & 0.73 & 0.84 & 0.73 & 0.46 \\
\hline $\mathrm{C} 1 / 6$ & 70.7 & 66.7 & 71.4 & $\mathrm{~N} / \mathrm{A}$ & 0.78 & 0.75 & 0.79 & $\mathrm{~N} / \mathrm{A}$ & 0.54 & 0.54 & 0.51 & N/A \\
\hline $\mathrm{C} 2 / 3$ & 63.4 & 74.1 & 71.4 & 94.4 & 0.72 & 0.81 & 0.79 & 0.96 & 0.39 & 0.50 & 0.62 & 0.73 \\
\hline $\mathrm{C} 2 / 4$ & 65.9 & 74.1 & 85.7 & 88.9 & 0.74 & 0.81 & 0.90 & 0.92 & 0.45 & 0.62 & 0.79 & 0.66 \\
\hline $\mathrm{C} 2 / 5$ & 75.6 & 74.1 & 76.2 & 72.2 & 0.82 & 0.81 & 0.83 & 0.79 & 0.64 & 0.62 & 0.65 & 0.52 \\
\hline C2/6 & 73.2 & 55.6 & 85.7 & $\mathrm{~N} / \mathrm{A}$ & 0.80 & 0.64 & 0.90 & $\mathrm{~N} / \mathrm{A}$ & 0.56 & 0.38 & 0.79 & N/A \\
\hline $\mathrm{C} 3 / 4$ & 68.3 & 70.4 & 76.2 & 83.3 & 0.76 & 0.78 & 0.83 & 0.88 & 0.39 & 0.58 & 0.62 & 0.60 \\
\hline C $3 / 5$ & 63.4 & 77.8 & 76.2 & 66.7 & 0.72 & 0.84 & 0.83 & 0.75 & 0.50 & 0.68 & 0.56 & 0.46 \\
\hline C3/6 & 61.0 & 59.3 & 66.7 & $\mathrm{~N} / \mathrm{A}$ & 0.69 & 0.68 & 0.75 & $\mathrm{~N} / \mathrm{A}$ & 0.29 & 0.38 & 0.56 & N/A \\
\hline C4/5 & 46.3 & 85.2 & 71.4 & 72.2 & 0.53 & 0.90 & 0.79 & 0.79 & 0.32 & 0.78 & 0.60 & 0.46 \\
\hline C4/6 & 63.4 & 66.7 & 81.0 & $\mathrm{~N} / \mathrm{A}$ & 0.72 & 0.75 & 0.86 & $\mathrm{~N} / \mathrm{A}$ & 0.24 & 0.49 & 0.66 & $\mathrm{~N} / \mathrm{A}$ \\
\hline C5/6 & 63.4 & 66.7 & 71.4 & $\mathrm{~N} / \mathrm{A}$ & 0.72 & 0.75 & 0.79 & N/A & 0.48 & 0.50 & 0.53 & N/A \\
\hline Average & 66.7 & 72.8 & 77.1 & 81.1 & 0.74 & 0.79 & 0.83 & 0.86 & 0.47 & 0.59 & 0.63 & 0.60 \\
\hline
\end{tabular}

Notes: Rounds 1-3 had 6 judges each, but round 4 had only 5 judges. N/A: Due to Round 4 only having 5 judges, the statistics comparing judge 6 to others are marked as N/A, i.e. such data not available

\subsubsection{Reliability and validity assessment}

The statistical analyses for survey data were conducted using SPSS and AMOS. Scale reliability and validity was tested through confirmatory factor analysis. The model fit was found to be unacceptable. In addition to the poor fit indexes, the model presents low item loadings onto latent constructs, and high modification indices. The average variance extracted (AVE) and composite reliability (CR) demonstrate statistics below generally accepted cut-off points. With a multinational sample, data inequivalence could impact analysis results. The model was thus also run for each individual country sample, but all produced similar and equally poor results, hence suggesting the issue lies with the scales and items, not with data inequivalence [1] and further scale development is needed.

\subsubsection{Item and scale refinement}

Following the advice of the two-stage approach by Menor and Roth (2007) the failed tests point to a need for item and scale refinement. First, an exploratory factor analysis (EFA) was conducted using the Oblimin rotation. The rotated component solution is presented in Table 3. The theoretically assumed loading into three factors did not hold. Five factors with Eigenvalues over 1 emerge. Only the mimetic pressure items form their own factor. The three items of coercive pressures deriving from market sources (suppliers and customers) load onto a separate factor, while the items on coercive pressure from regulatory sources load onto another. One item from normative and coercive pressures load onto a separate factor with no apparent unifying theme (parent company pressure and impact of education). The results would thus appear to support a small section of institutional theory literature that has explicitly discussed both a market and regulatory coercive pressure (Shi et al., 2008) or one of the two (Cheng, 2010; Liu et al., 2010; Zorn et al., 2011), i.e. coercive pressure is actually being represented by two constructs. We note the need to respecify the definitions of constructs, followed by new testing. We thus returned to the "Front end" stage of the Menor and Roth (2007) approach and reviewed the existing set of items with the evidence from this first "Back end" testing.

Given the previous testing of the scales with survey data pointed to coercive pressure splitting into two constructs, we proceeded to develop two separate definitions for these two kinds of coercive pressures, and reviewed the pool of items to ensure sufficient numbers of items exist for both coercive pressures. We still adhere to the general definition of coercive pressure as provided earlier in the literature review, but now provide additional definitions for each of the sub-pressures. Specifically, we now define coercive regulatory pressure construct as pressure exerted by official regulatory institutions with the power to impact firm behavior. Coercive market pressure construct is defined as pressure exerted to the firm by other market actors it depends on for resources and performance (e.g. customers and suppliers). To ensure both coercive pressure constructs have enough items as well as to test whether some items discarded due to lack of consensus by the academic judges should be retained, we extend the number of items. New items are derived from another review of institutional theory literature (mostly for the two coercive pressure scales) as well as from the previous q-sorting rounds with academics. The item on parent company coercive pressure is removed as further reflection shows it does not fit with our construct definition focusing on external pressure sources. Appendix 4 details the list of items carried over from the first survey test, retained back from the initial q-sorts with academics or developed new (and the supporting literature).

\subsection{Results from second q-sorting with practitioners}

The second q-sorting was done with the refined set of items as explained above. The item placement ratios are shown in Table 4, while the interjudge agreement statistics are in 
Table 3 Descriptive statistics from survey 1 (IPS2) and exploratory factor analysis using Oblimin rotation (N = 277)

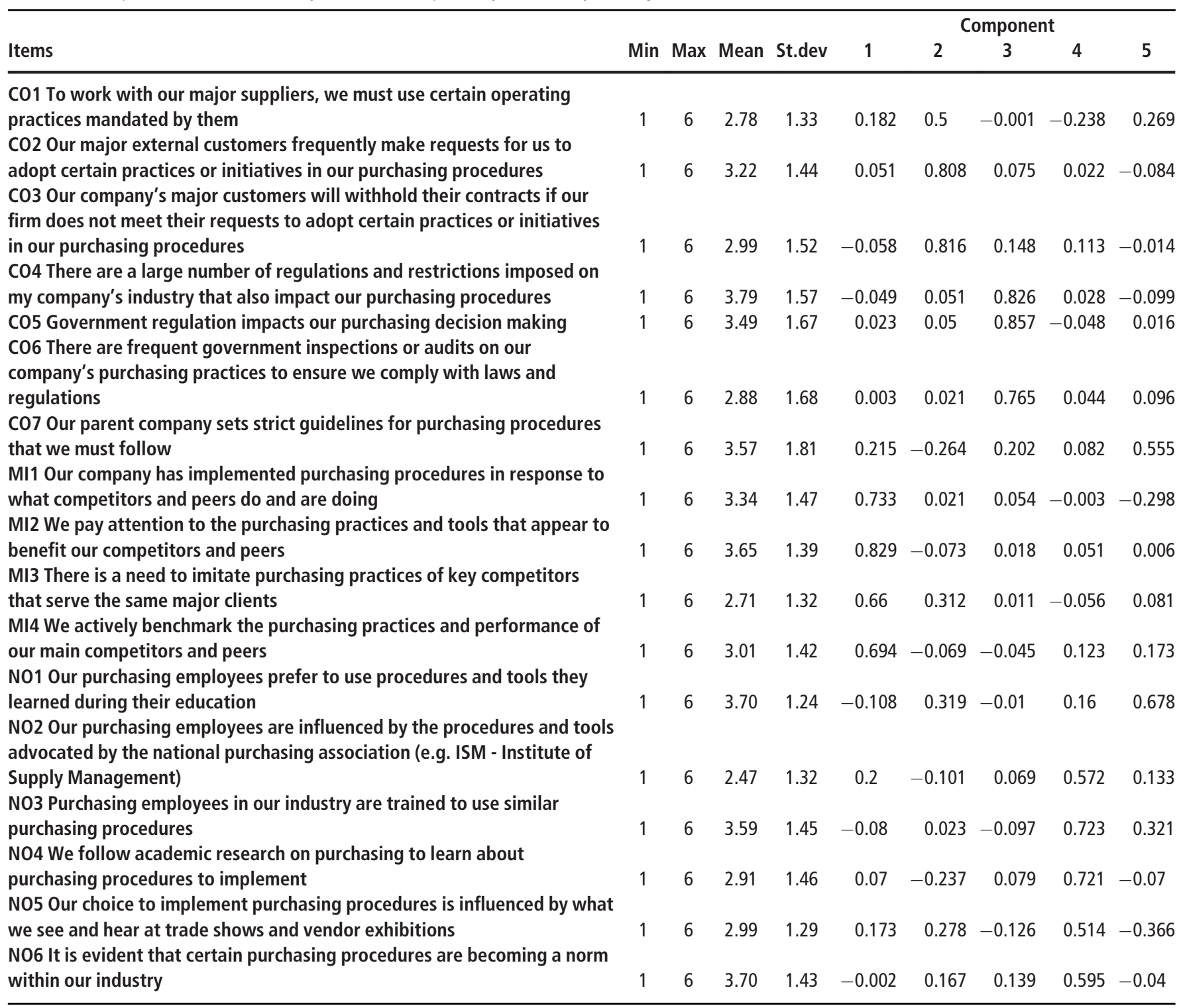

Table 5. The first round, with 27 items altogether for the 4 constructs, results in an overall item placement ratio of $75.1 \%$, i.e. exceeding the cut-off already. Mimetic and normative pressure constructs, however, fall below the cut-off still. Furthermore, as Cohen's Kappa is on average only 0.56, we proceed to a second practitioner q-sort. As a result of the first round, though, five items are removed and not retained for the second survey (Appendix 4).

For the second practitioner q-sort, the item placement ratio overall is excellent, 92.4\%, and each individual construct passes the cut-off. Also, other interjudge agreements pass the cut-off, including the more conservative Cohen's Kappa. All 22 items are thus retained, and we proceed to a second survey test.

\subsection{Results from second survey testing}

The descriptive statistics for the institutional items from the second survey are available in Table 6. First, a confirmatory factor analysis (CFA) was conducted for the four pressure constructs in AMOS. All 22 items were initially included in the model linked to the constructs based on the practitioner qsorting. This initial model does not provide sufficient model fit indices, nor do the AVE and CR values for individual constructs pass the cut-offs. Upon closer inspection of the statistics, it appears that a few items for each construct suffer from low loading unto their respective constructs (standardised loadings ranging between $0.3-0.5$, and three of these additionally portray a high modification index). Upon closer inspection, for coercive market pressure the items with low loadings (CO7new and CO9new) reflect the stakeholder pressures (media and consumers), and thus differ from the rest of the items that focus on supply chain partners upstream and downstream. Removing them based on the low loadings could thus also be seen to increase the theoretical unity of the coercive market pressure construct. Similarly, for coercive regulatory pressures, the items with low loadings (CO8new and CO10new) relate to incentives from the government and EU 
Table 4 Item placement ratios for both sorting rounds with practitioner judges

\begin{tabular}{|c|c|c|c|c|c|c|c|}
\hline Categories & Coercive regulatory & Coercive market & Mimetic & Normative & Unused & Total & Ratio \% \\
\hline \multicolumn{8}{|l|}{ Round 1} \\
\hline Coercive regulatory & 31 & 3 & 0 & 2 & 0 & 36 & 86.11 \\
\hline Coercive market & 3 & 29 & 0 & 4 & 0 & 36 & 80.56 \\
\hline Mimetic & 6 & 0 & 29 & 7 & 0 & 42 & 69.05 \\
\hline Normative & 5 & 7 & 4 & 31 & 1 & 48 & 64.58 \\
\hline Total & 45 & 39 & 33 & 44 & 1 & 162 & $75.07^{a}$ \\
\hline \multicolumn{8}{|l|}{ Round 2} \\
\hline Coercive regulatory & 35 & 1 & 0 & 0 & & 36 & 97.22 \\
\hline Coercive market & 1 & 29 & 0 & 0 & & 30 & 96.67 \\
\hline Mimetic & 3 & 0 & 26 & 1 & & 30 & 86.67 \\
\hline Normative & 0 & 0 & 4 & 32 & & 36 & 88.89 \\
\hline Total & 39 & 30 & 30 & 33 & 0 & 132 & $92.36^{a}$ \\
\hline
\end{tabular}

regulations. It appears that respondents do not consider incentives or guidelines (which by definition are not mandatory) as strongly coercive as national regulations that are enforced by the law. For mimetic pressure, the items with low loadings (MI1 and MI3) reflect in their wording a stronger pressure than those items with a high loading, and perhaps for this reason do not reflect the mimetic pressure as well, which more relies on reacting to uncertainty than to force. For normative, the items with low loading (NO1 and NO3) relate to education and training. This seems to suggest that respondents perceive norms in the industry mostly coming from industry peers and can be diffused through industrial associations, whereas education and training do not really play a major role. We therefore remove these items, to improve the theoretical unity of the constructs and the fit statistics.
The final model thus consists of 3-item measurement scales for mimetic, coercive market and coercive regulatory pressures and a 4 -item measurement scale for normative pressures. The model fit indexes are available in Table 7 . While the RMSEA somewhat exceeds the cut-off value, this is likely to be due to the small sample size $(n=70)$. Kenny et al. (2015) have shown the RMSEA to be problematic with small sample sizes (at or below 100), with standard cut-offs leading to rejecting a significant portion of correctly specified models.

The AVE and the CR are measured for each of the constructs in the model. The AVE estimates the amount of variance captured by the construct compared to the variance related to measurement error (Menor and Roth, 2007). The cut-off value is 0.5 (Hair et al., 2005), though previous studies (Menor and Roth, 2007; Rosenzweig and Roth, 2007) have retained

Table 5 Interjudge agreement statistics for both rounds of practitioner q-sorting

\begin{tabular}{|c|c|c|c|c|c|c|}
\hline \multirow{2}{*}{$\begin{array}{l}\text { Interjudge } \\
\text { combination } \mathrm{C}_{\mathrm{a} / \mathrm{b}}\end{array}$} & \multicolumn{2}{|c|}{$\begin{array}{l}\text { Interjudge agreement } \\
\text { (by sorting round) }\end{array}$} & \multicolumn{2}{|c|}{$\begin{array}{l}\text { Perreault and Leigh's } I_{\mathrm{r}} \\
\text { (by sorting round) }\end{array}$} & \multicolumn{2}{|c|}{$\begin{array}{c}\text { Cohen's k } \\
\text { (by sorting round) }\end{array}$} \\
\hline & Round $1(\%)$ & Round $2(\%)$ & Round 1 & Round 2 & Round 1 & Round 2 \\
\hline $\mathrm{C} 1 / 2$ & 55.6 & 72.7 & 0.64 & 0.80 & 0.50 & 0.63 \\
\hline $\mathrm{C} 1 / 3$ & 74.1 & 90.9 & 0.81 & 0.94 & 0.70 & 0.88 \\
\hline $\mathrm{C} 1 / 4$ & 70.4 & 86.4 & 0.78 & 0.90 & 0.57 & 0.82 \\
\hline $\mathrm{C} 1 / 5$ & 74.1 & 90.9 & 0.81 & 0.94 & 0.62 & 0.88 \\
\hline $\mathrm{C} 1 / 6$ & 85.2 & N/A & 0.90 & $\mathrm{~N} / \mathrm{A}$ & 0.77 & $\mathrm{~N} / \mathrm{A}$ \\
\hline $\mathrm{C} 2 / 3$ & 48.2 & 72.7 & 0.56 & 0.80 & 0.32 & 0.64 \\
\hline $\mathrm{C} 2 / 4$ & 63.0 & 68.2 & 0.71 & 0.76 & 0.37 & 0.57 \\
\hline $\mathrm{C} 2 / 5$ & 66.7 & 72.7 & 0.75 & 0.80 & 0.36 & 0.64 \\
\hline $\mathrm{C} 2 / 6$ & 63.0 & $\mathrm{~N} / \mathrm{A}$ & 0.71 & $\mathrm{~N} / \mathrm{A}$ & 0.46 & $\mathrm{~N} / \mathrm{A}$ \\
\hline $\mathrm{C} 3 / 4$ & 74.1 & 86.4 & 0.81 & 0.90 & 0.66 & 0.82 \\
\hline $\mathrm{C} 3 / 5$ & 85.2 & 100 & 0.90 & 1 & 0.71 & 1 \\
\hline $\mathrm{C} 3 / 6$ & 88.9 & $\mathrm{~N} / \mathrm{A}$ & 0.93 & $\mathrm{~N} / \mathrm{A}$ & 0.80 & $\mathrm{~N} / \mathrm{A}$ \\
\hline $\mathrm{C} 4 / 5$ & 59.3 & 86.4 & 0.68 & 0.90 & 0.37 & 0.82 \\
\hline $\mathrm{C} 4 / 6$ & 77.78 & N/A & 0.84 & $\mathrm{~N} / \mathrm{A}$ & 0.60 & $\mathrm{~N} / \mathrm{A}$ \\
\hline C5/6 & 81.5 & $N / A$ & 0.87 & $N / A$ & 0.60 & $N / A$ \\
\hline Average & 71.1 & 82.7 & 0.78 & 0.87 & 0.56 & 0.77 \\
\hline
\end{tabular}

Notes: Rounds 1 had 6 judges, round 2 had 5 judges. N/A: Due to Round 2 only having 5 judges, the statistics comparing judge 6 to others are marked as N/A, i.e. such data not available 
constructs with lower values along with a suggestion for further refinement of the items. For CR, a minimum of 0.70 is recommended (Fornell and Larcker, 1981). Table 8 provides these, and the standardised loadings for each item, for the final model.

Mimetic, coercive regulatory and coercive market pressure pass the cut-off for AVE and CR, and the normative pressure nearly for CR (with a value of 0.69), but it is below the cut-off for AVE. The item loadings on the construct are reasonable, but not as high as on the other constructs. We can thus confirm the mimetic, coercive market and coercive regulatory pressures only based on the second survey data, and only cautiously recommend the use of the normative construct as it did pass the q-sorting test with practitioners (and an earlier version a qsorting with academics). These final measurement scales and their items are in Table 8.

\section{Discussion, future research and limitations}

Different scales of key theoretical constructs hinder the comparison of past studies as well as their theoretical relevance (Flatten et al., 2011). A review of previous measurement of institutional pressures revealed extensive use of proxy measures (often focused on the outcome of the pressure, i.e. isomorphism rather than the pressure itself), grouped constructs of external pressures ignoring the multidimensionality of the construct, and practice-tied pressure measurement scales that do not allow for continuity and comparison between research settings. The scale development also revealed shortcomings in past scales used, such as the use of antecedents of institutional pressures to measure the pressures themselves. Therefore, there is a need to develop scales that reflect the pressures themselves as theoretical constructs.

The scale development here started from the premise of DiMaggio and Powell (1983): it was expected that a measurement scale is developed for three institutional pressures. However, the first empirical testing revealed a fourconstruct structure emerging. What we theoretically discuss as one construct, coercive pressure, manifests itself as two empirically distinct constructs: coercive market pressure and coercive regulatory pressure. This demonstration of the split of the coercive pressure into two separate constructs presents an unexpected theoretical contribution, i.e. four separate institutional pressures exist. While many previous empirical

Table 6 Descriptive statistics for 2 nd survey (Italy) $(\mathrm{N}=70)$

\begin{tabular}{|c|c|c|c|c|c|}
\hline Items & & Min & Max & Mean & St.dev \\
\hline C01 & To work with our major suppliers, we must use certain operating practices mandated by them & 1 & 7 & 3.49 & 1.60 \\
\hline $\mathrm{CO} 2$ & $\begin{array}{l}\text { Our major external customers frequently make requests for us to adopt certain practices or } \\
\text { initiatives in our purchasing procedures }\end{array}$ & 1 & 7 & 4.12 & 1.70 \\
\hline Co7new & We sometimes have to modify our purchasing practices in response to consumer preferences & 1 & 7 & 4.71 & 1.69 \\
\hline $\mathrm{CO3}$ & $\begin{array}{l}\text { Our company's major customers will withhold their contracts if our firm does not meet their } \\
\text { requests to adopt certain practices or initiatives in our purchasing procedures }\end{array}$ & 1 & 7 & 4.1 & 1.69 \\
\hline Co8new & $\begin{array}{l}\text { Our company's major suppliers will withhold their contracts if our firm does not meet their } \\
\text { requests to adopt certain practices or initiatives in our purchasing procedures }\end{array}$ & 1 & 7 & 3.71 & 1.56 \\
\hline Co9new & We sometimes have to modify our purchasing practices in response to media actions & 1 & 7 & 3.17 & 1.69 \\
\hline $\mathrm{CO4}$ & $\begin{array}{l}\text { There are a large number of regulations and restrictions imposed on my company's industry that } \\
\text { also impact our purchasing procedures }\end{array}$ & 1 & 7 & 4.99 & 1.59 \\
\hline $\mathrm{CO6}$ & $\begin{array}{l}\text { There are frequent government inspections or audits on our company's purchasing practices to } \\
\text { ensure we comply with laws and regulations }\end{array}$ & 1 & 7 & 4.47 & 1.94 \\
\hline C010new & $\begin{array}{l}\text { We receive financial incentives from the government to adopt certain practices in our purchasing } \\
\text { procedures }\end{array}$ & 1 & 6 & 2.14 & 1.39 \\
\hline $\mathrm{CO5}$ & Government regulation impacts our purchasing decision making & 1 & 7 & 4.21 & 1.97 \\
\hline Co8new & European Union legislation (e.g. directives) impacts the purchasing procedures we use & 1 & 7 & 4.41 & 1.83 \\
\hline MI1 & $\begin{array}{l}\text { Our company has implemented purchasing procedures in response to what competitors and } \\
\text { peers do and are doing }\end{array}$ & 1 & 7 & 4.43 & 1.52 \\
\hline MI2 & $\begin{array}{l}\text { We pay attention to the purchasing practices and tools that appear to benefit our competitors } \\
\text { and peers }\end{array}$ & 1 & 7 & 3.97 & 1.62 \\
\hline MI3 & $\begin{array}{l}\text { There is a need to imitate purchasing practices of key competitors that serve the same major } \\
\text { clients }\end{array}$ & 1 & 7 & 4.49 & 1.66 \\
\hline M14 & $\begin{array}{l}\text { We actively benchmark the purchasing practices and performance of our main competitors and } \\
\text { peers }\end{array}$ & 1 & 7 & 3.82 & 1.65 \\
\hline MI5new & We pay attention to the purchasing practices and tools used and adopted by our key competitors & 1 & 7 & 3.77 & 1.64 \\
\hline N01 & Our purchasing employees prefer to use procedures and tools they learned during their education & 1 & 7 & 4.1 & 1.48 \\
\hline NO2 & $\begin{array}{l}\text { Our purchasing employees are influenced by the procedures and tools advocated by the national } \\
\text { purchasing association (e.g. ISM - Institute of Supply Management) }\end{array}$ & 1 & 6 & 3.17 & 1.66 \\
\hline NO3 & Purchasing employees in our industry are trained to use similar purchasing procedures & 1 & 7 & 4.73 & 1.49 \\
\hline N04 & We follow academic research on purchasing to learn about purchasing procedures to implement & 1 & 7 & 3.79 & 1.68 \\
\hline N06 & It is evident that certain purchasing procedures are becoming a norm within our industry & 1 & 7 & 5.26 & 1.49 \\
\hline N07new & $\begin{array}{l}\text { Opinions of consulting companies and external auditors on the best practices in purchasing } \\
\text { procedures influence our procedures }\end{array}$ & 1 & 7 & 4.57 & 1.58 \\
\hline
\end{tabular}


Table 7 Model fit for second survey test $(\mathrm{N}=70)$

\begin{tabular}{|c|c|c|}
\hline Fit statistics/index & Score for original 3 construct model & Recommended valuea \\
\hline$\chi^{2}$ & $85.96(55 \mathrm{df}) b$ & Non-significant \\
\hline Normed $\chi^{2}$ & 1.56 & $1.0<$ and $<3.0$ \\
\hline RMSEA (root mean square error of approximation) & 0.09 & $<0.06$ \\
\hline CFI (Comparative Fit Index) & 0.91 & $>0.95(0.90)$ \\
\hline NFI (Normed Fit Index) & 0.80 & $>0.95(0.90)$ \\
\hline
\end{tabular}

studies may have only included either market-place based coercive pressures (mostly) or regulatory coercive pressures into their operationalization (Cheng, 2010; Jin et al., 2012; Henderson et al., 2012; Ke et al., 2009; Liu et al., 2010), the division to two constructs has not been explicit before.

While the measurement scales for mimetic, coercive market and coercive regulatory pressures passed the generally accepted cut-offs in statistical testing for constructs, the normative pressure measurement scale fell slightly below those values, and we can thus only cautiously confirm it based on the practitioner q-sorting but not the final survey test. The sample size in our final survey used for scale testing was rather small $(n=70)$, which could partly explain the low AVE and CR. Based on the literature review, two rounds of q-sorting and two surveys we believe the items are tapping to the underlying normative pressures in the purchasing environment. However, as the construct did not pass all statistical criteria, we would recommend future research to use the 6 items that have passed the q-sorting with practitioners (Appendix 4) and conduct further refinement.

The institutional perspective is now a dominant lens within organization theory (Greenwood et al., 2008), and recent studies are showing challenges that arise when organizations confront incompatible prescriptions from multiple institutional logics (Greenwood et al., 2011; Ramus et al., 2017). Yet, OM/ SCM studies addressing institutional complexity are scarce. Most previous studies privilege a positivistic rather than a problemistic view of institutional theory and explore

Table 8 Assessment of reliability and construct validity for new measurement model $(N=70)$

\begin{tabular}{|c|c|c|c|c|c|c|c|}
\hline \multicolumn{3}{|c|}{ Variables and items } & \multirow{2}{*}{$\begin{array}{c}\begin{array}{c}\text { Standardized } \\
\text { loadings }\end{array} \\
0.807\end{array}$} & \multirow{2}{*}{$\begin{array}{c}\begin{array}{c}\text { Standard } \\
\text { error }\end{array} \\
0.126\end{array}$} & \multirow{2}{*}{$\begin{array}{r}\text { t- } \\
\text { value } \\
7.18\end{array}$} & \multirow{2}{*}{$\frac{\mathrm{CR}}{0.80}$} & \multirow{2}{*}{$\frac{\text { AVE }}{0.59}$} \\
\hline $\begin{array}{l}\text { Coercive } \\
\text { market }\end{array}$ & $\mathrm{CO} 2$ & $\begin{array}{l}\text { Our major external customers frequently make requests for us to adopt } \\
\text { certain practices or initiatives in our purchasing procedures }\end{array}$ & & & & & \\
\hline \multirow[t]{2}{*}{ pressure } & $\mathrm{CO3}$ & $\begin{array}{l}\text { Our company's major customers will withhold their contracts if our firm } \\
\text { does not meet their requests to adopt certain practices or initiatives in } \\
\text { our purchasing procedures }\end{array}$ & 0.884 & $-a$ & $-a$ & & \\
\hline & Co8new & $\begin{array}{l}\text { Our company's major suppliers will withhold their contracts if our firm } \\
\text { does not meet their requests to adopt certain practices or initiatives in } \\
\text { our purchasing procedures }\end{array}$ & 0.569 & 0.123 & 4.96 & & \\
\hline $\begin{array}{l}\text { Coercive } \\
\text { regulatory }\end{array}$ & $\mathrm{CO} 4$ & $\begin{array}{l}\text { There are a large number of regulations and restrictions imposed on my } \\
\text { company's industry that also impact our purchasing procedures }\end{array}$ & 0.677 & 0.087 & 6.59 & 0.87 & 0.69 \\
\hline \multirow[t]{2}{*}{ pressure } & $\mathrm{CO5}$ & Government regulation impacts our purchasing decision making & 0.927 & $-a$ & $-a$ & & \\
\hline & $\mathrm{CO6}$ & $\begin{array}{l}\text { There are frequent government inspections or audits on our company's } \\
\text { purchasing practices to ensure we comply with laws and regulations }\end{array}$ & 0.865 & 0.082 & 9.75 & & \\
\hline \multirow[t]{3}{*}{$\begin{array}{l}\text { Mimetic } \\
\text { pressure }\end{array}$} & $\mathrm{MI2}$ & $\begin{array}{l}\text { We pay attention to the purchasing practices and tools that appear to } \\
\text { benefit our competitors and peers }\end{array}$ & 0.91 & 0.072 & 13.19 & 0.92 & 0.79 \\
\hline & MI4 & $\begin{array}{l}\text { We actively benchmark the purchasing practices and performance of our } \\
\text { main competitors and peers }\end{array}$ & 0.793 & 0.088 & 9.47 & & \\
\hline & MI5new & $\begin{array}{l}\text { We pay attention to the purchasing practices and tools used and } \\
\text { adopted by our key competitors }\end{array}$ & 0.956 & $-a$ & $-a$ & & \\
\hline \multirow[t]{4}{*}{$\begin{array}{l}\text { Normative } \\
\text { pressure }\end{array}$} & NO2 & $\begin{array}{l}\text { Our purchasing employees are influenced by the procedures and tools } \\
\text { advocated by the national purchasing association (e.g. ISM - Institute of } \\
\text { Supply Management) }\end{array}$ & 0.612 & 0.190 & 4.21 & 0.69 & 0.37 \\
\hline & NO4 & $\begin{array}{l}\text { We follow academic research on purchasing to learn about purchasing } \\
\text { procedures to implement }\end{array}$ & 0.493 & 0.184 & 3.51 & & \\
\hline & N06 & $\begin{array}{l}\text { It is evident that certain purchasing procedures are becoming a norm } \\
\text { within our industry }\end{array}$ & 0.54 & 0.183 & 3.85 & & \\
\hline & N07new & $\begin{array}{l}\text { Opinions of consulting companies and external auditors on the best } \\
\text { practices in purchasing procedures influence our procedures }\end{array}$ & 0.749 & $-a$ & $-a$ & & \\
\hline
\end{tabular}

Note: ${ }^{a}$ Item fixed to 1 to set the scale 
institutional pressures as the antecedent to the adoption of certain practices (Zhu et al., 2013). However, the challenges of making sense and responding to different institutional logics that manifest across the supply chain remain relatively less explored (with some exceptions, e.g. Pullman et al., 2018). Having more detailed and fine-grained scales for institutional pressures at researchers' disposal can contribute to knowledge creation in this research domain. Indeed, a clear separation of different types of pressures is the basic premise to study which types of potentially conflicting prescriptions follow from each pressure and how organizations and supply chains differ in their responses. We thus see our scale development as an important first step in opening further research avenues to understand the complexity of institutional pressures within which managers operate.

\subsection{Future research}

Naturally, more theoretical contributions of this paper will follow when the scales are used and related to other theoretical constructs or to organizational performance, i.e. when they become the standard used in studies on the impact of institutional pressures. This will then also serve to demonstrate their nomological validity, i.e. their theoretical connection to other constructs. We suggest a good starting point would be replication studies of some of the past institutional pressure investigations that used proxies and grouped constructs to test how the results may change and/or become refined.

Many other theories would benefit from scale development efforts, for example the resource-based view, where most studies still lack detailed operationalization of the theory's critical constructs. Potentially for other organizational theories scale development could also reveal unexpected findings regarding their core constructs, as happened here with the splitting of coercive pressure into two separate constructs. In general, past scale studies in management research, and especially within SCM, have mostly focused on constructs other than those directly related to organizational theories (see e.g. Zhu et al. (2008) for Green SCM or Rosenzweig and Roth (2007) for B2B seller competence), even though theoretical constructs are likely to experience the most replication in future research. Based on our experiences here we recommend the use of practitioner judges more than academic ones in q-sorting. Overall, we feel our iterative multi-step approach to scale development here serves to emphasise the value of the Menor and Roth (2007) procedure in future scale development research.

The scales were developed here within the purchasing context but can easily be modified for other areas of management research through rewording. Already by replacing the word "purchasing" with another function such as "marketing" or "logistics" would serve to enable testing of many of the items in other contexts. This is an important and necessary extension of the current study, to determine whether similar aspects of each pressure are relevant in all contexts. Therefore, it is suggested that the starting point for scale usage in other fields could be the set of items resulted from the second, practitioner q-sorting in this study rather than the more limited set of items that remained after empirical testing.

\subsection{Limitations}

In both rounds of survey data collection (and the practitioner qsort), we only focused on service and manufacturing sectors, excluding retail and the public sector. It is possible that the developed measurement scales as such would not be suitable for these sectors, but would need item additions or changes, as for example with the retail sector pressures from consumers and various advocacy groups are likely to get a higher role compared to the manufacturing and service sectors. Specifically, items confirmed in the practitioner q-sort but not in the final survey test such as "We sometimes have to modify our purchasing practices in response to consumer preferences/media actions" should perhaps be included in the measurement scale for testing purposes when using the constructs in a retail sector survey. Furthermore, related to sectors, our limited sample size in the second, final, survey used for construct confirmation did not allow for a two-group confirmatory measurement model contrasting the constructs in the two sectors.

While we controlled for industry and company size in terms of non-response bias in our surveys, we could not control for factors related to e.g. purchasing performance of the company or the educational level of the respondent (which could impact the perception of normative pressures) between respondents and non-respondents, and must note it as a possible limitation.

The first survey test, which did not lead to a satisfactory solution for the constructs, was a multi-country survey. Potentially languages, translation and equivalence issues could all have impacted the results. Though as testing the threeconstruct solution as originally derived from literature did not work with any of the individual country data sets either, we consider this unlikely. Rather, the split of the coercive pressure construct was more likely the reason for the poor model fit in the initial survey test. The second, final testing was conducted with one country, Italy, only. We thus urge future use of the scales in other countries as well, and potentially in such instances using the larger set of items confirmed in the practitioner q-sorting if cultural differences compared to Italy that impact institutional pressures are likely in the study context. Specifically, the item on "European Union legislation impacts the purchasing procedures we use" is naturally only suited for surveys within the EU and local adaptations are needed elsewhere.

As noted in our methodology section, we controlled for social desirability mainly through the design of the survey, including e.g. anonymity and wording of items. Furthermore, the items in the measurement scales do not relate to undesirable actions of the respondent, and hence do not cause a need to withhold information. However, as the items do relate to the respondents admitting to being subject to outside pressure, we cannot rule out the existence of social desirability, and were unable to statistically control for it. We hence must note it as a limitation and suggest future research could try to collect e.g. chain level data to provide data triangulation on the pressures felt from suppliers and customers.

\section{Conclusions}

Zhu, Sarkis and Lai (2008) state that identifying measurement scales is paramount for emerging theories to ensure robustness and advancement of science. The authors would argue that it is 
even more pressing to do so for theories that have long been and continue to be essential in our field, such as institutional theory. To reduce the occurrence of weak linkage between theory and measures, this paper utilised a systematic approach to develop a set of scales (Rosenzweig and Roth, 2007) for the pressure constructs central to institutional theory and evaluated their measurement properties. This type of iterative design and refinement of scales is necessary for empirical research (Froehle and Roth, 2004). The items were created through a review of literature and tested with two rounds of q-sorting and two surveys in the manufacturing and service industries. It is hoped that they will become a valuable tool for empirical researchers wishing to study institutional theory in SCM research specifically and management research more broadly.

To date, the construct operationalisation of institutional pressures has been rather unrefined (Kauppi, 2013). Researchers have urged each other to address critical issues in methodology related to institutional theory and improve rigour in the constructs (Yang and Su, 2014). Thus, the main contributions of this paper are to the research community studying institutional theory and the impact of pressures on a variety of practices adopted such as sustainable SCM or various technologies. The measurement scales developed are a first step towards a more compelling method to empirically test the theory, and to understand the process leading to isomorphism rather than the level of isomorphism per se. Empirical measures that distinguish the elements within each pressure (i.e. multidimensional as opposed to a grouped construct of institutional pressures), also provide a richer and more nuanced understanding of how managerial practices are shaped by the institutions around them.

Clarity of constructs and measures is expected to lead to more cumulative and impactful research (Gatignon et al., 2002). Widespread use of these measurement scales could enable more generalizations and comparability within various institutional theory studies than is currently possible with for example the practice-specific pressure items often used. The more detailed understanding of the forces shaping managerial action that the developed scales offer can act as a mechanism to help firms and managers understand better their own (employees') behaviour and how it is impacted by external forces. As several previous studies point to externally motivated adoption of business practices having poorer performance than adoption due to internal motivations (Martínez-Costa et al., 2008; Nair and Prajogo, 2009; Adebanjo et al., 2016), this increased understanding of institutional pressures can assist managers in evaluating their own adoption decisions more closely, and help avoid "jumping on the bandwagon" too often; especially when it comes to mimetic and normative pressures. Proxy measures of isomorphism can only show the impact of institutional measures to past adoption, and practice-tied measures only help in a single managerial decision. Studies using multidimensional measurement scales of the institutional pressures impacting managers can provide them an understanding of the overall environment within which new practices become adopted in their firms and supply chains and, more importantly, of the external forces that impact their decision-making. This can provide managers with tools to understand how legitimacy becomes associated with business practices, and how they might be able to manipulate the institutionalization of selected practices (Kauppi, 2013) or help drive institutionalization of their preferred practices in, e.g. supply chain sustainability or digitalization.

\section{Note}

1 As the constructs fail to pass the confirmatory factor analysis with the first data collection overall and per country, and a new data collection is warranted, we will not include the CFA statistics nor equivalence testing so as not to unduly increase manuscript length.

\section{References}

Adebanjo, D., Teh, P.L. and Ahmed, P.K. (2016), "The impact of external pressure and sustainable management practices on manufacturing performance and environmental outcomes", International fournal of Operations $\mathcal{E}$ Production Management, Vol. 36 No. 9, pp. 995-1013.

Agarwal, A., Giraud-Carrier, F.C. and Li, Y. (2018), "A mediation model of green supply chain management adoption: the role of internal impetus", International fournal of Production Economics, Vol. 205, pp. 342-358.

Alvesson, M. and Spicer, A. (2019), "Neo-institutional theory and organization studies: a mid-life crisis?", Organization Studies, Vol. 40 No. 2, pp. 199-218.

Ashill, N. and Jobber, D. (2010), "Measuring state, effect, and response uncertainty: theoretical construct development and empirical validation", foumal of Management, Vol. 36 No. 5, pp. 1278-1308.

Basaglia, S., Caporarello, L., Magni, M. and Pennarola, F. (2009), "Environmental and organizational drivers influencing the adoption of VoIP", Information Systems and E-Business Management, Vol. 7 No. 1, pp. 103-118.

Baxter, R. (2009), "Reflective and formative metrics of relationship value: a commentary essay", fournal of Business Research, Vol. 62 No. 12, pp. 1370-1377.

Bhakoo, V. and Choi, T. (2013), "The iron cage exposed: institutional pressures and heterogeneity across the healthcare supply chain", fournal of Operations Management, Vol. 31 No. 6, pp. 432-449.

Boiral, O. and Roy, M. (2007), "ISO 9000: integration rationales and organizational impacts", International fournal of Operations E Production Management, Vol. 27 No. 2, pp. 226-247.

Brandau, M., Endenich, C., Trapp, R. and Hoffjan, A. (2013), "Institutional drivers of conformity-evidence for management accounting from Brazil and Germany", International Business Review, Vol. 22 No. 2, pp. 466-479.

Braunscheidel, M.J., Hamister, J.W., Suresh, N.C. and Star, H. (2011), "An institutional theory perspective on six sigma adoption", International fournal of Operations \& Production Management, Vol. 31 No. 4, pp. 423-451.

Byrne, B. (2010), Structural Equation Modeling with AMOS: Basic Concepts, Applications, and Programming, 2nd ed., Routledge, New York, NY.

Carter, C. (2000), "Precursors of unethical behavior in global supplier management", The fournal of Supply Chain Management, Vol. 36 No. 1, pp. 45-56. 
Castka, P. and Balzarova, M. (2008), "ISO 26000 and supply chains - on the diffusion of the social responsibility standard", International fournal of Production Economics, Vol. 111 No. 2, pp. 274-286.

Cheng, H. (2010), "Seeking knowledge or gaining legitimacy? Role of social networks on new practice adoption by OEM suppliers", Fournal of Business Research, Vol. 63 No. 8, pp. 824-831.

Cheng, H.L. and Yu, C.M. (2008), "Institutional pressures and initiation of internationalization: evidence from taiwanese small-and medium-sized enterprises", International Business Review, Vol. 17 No. 3, pp. 331-348.

Combs, J.G., Michael, S.C. and Castrogiovanni, G.J. (2009), "Institutional influences on the choice of organizational form: the case of franchising", Fournal of Management, Vol. 35 No. 5, pp. 1268-1290.

Dasborough, M. and Sue-Chan, K. (2002), "The role of transaction costs and institutional forces in the outsourcing of recruitment", Asia Pacific Fournal of Human Resources, Vol. 40 No. 3, pp. 306-321.

Deephouse, D. (1996), "Does isomorphism legitimate?", Academy of Management fournal, Vol. 39 No. 4, pp. 1024-1039.

DiMaggio, P. and Powell, W. (1983), "The iron cage revisited: institutional isomorphism and collective rationality in organizational fields", American Sociological Review, Vol. 48 No. 2, pp. 147-160.

Dubey, R., Gunasekaran, A. and Ali, S.S. (2015), "Exploring the relationship between leadership, operational practices, institutional pressures and environmental performance: a framework for green supply chain", International fournal of Production Economics, Vol. 160, pp. 120-132.

Dubey, R., Gunasekaran, A., Childe, S.J., Papadopoulos, T., Hazen, B., Giannakis, M. and Roubaud, D. (2017), "Examining the effect of external pressures and organizational culture on shaping performance measurement systems (PMS) for sustainability benchmarking: some empirical findings", International fournal of Production Economics, Vol. 193, pp. 63-76.

Dubey, R., Gunasekaran, A., Childe, S.J., Papadopoulos, T., Hazen, B.T. and Roubaud, D. (2018), "Examining top management commitment to TQM diffusion using institutional and upper echelon theories", International Fournal of Production Research, Vol. 56 No. 8, pp. 2988-3006.

Flatten, T., Engelen, A., Zahra, S. and Brettel, M. (2011), “A measure of absorptive capacity: scale development and validation", European Management fournal, Vol. 29 No. 2, pp. 98-116.

Fornell, C. and Larcker, D. (1981), "Evaluating structural equation models with unobservable variables and measurement error", fournal of Marketing Research, Vol. 18 No. 1, pp. 39-50.

Froehle, C. and Roth, A. (2004), "New measurement scales for evaluating perceptions of the technology-mediated customer service experience", Fournal of Operations Management, Vol. 22 No. 1, pp. 1-21.

Frohlich, M. (2002), "Techniques for improving response rates in OM survey research", fournal of Operations Management, Vol. 20 No. 1, pp. 53-62.
Gatignon, H., Tushman, M., Smith, W. and Anderson, P. (2002), "A structural approach to assessing innovation: construct development of innovation locus, type, and characteristics", Management Science, Vol. 48 No. 9, pp. 1103-1122.

Gopal, A. and Gao, G. (2009), "Certification in the indian offshore IT services industry", Manufacturing \& Service Operations Management, Vol. 11 No. 3, pp. 471-492.

Greenwood, R., Oliver, C., Suddaby, R. and SahlinAndersson, K. (2008), The Sage Handbook of Organizational Institutionalism, Sage.

Greenwood, R., Raynard, M., Kodeih, F., Micelotta, E.R. and Lounsbury, M. (2011), "Institutional complexity and organizational responses", Academy of Management Annals, Vol. 5 No. 1, pp. 317-371.

Hair, J., Black, W., Babin, B., Anderson, R. and Tatham, R. (2005), Multivariate Data Analysis, 6th Ed. Prentice Hall.

Handley, S. and Benton, W.C. Jr. (2012), "The influence of exchange hazards and power on opportunism in outsourcing relationships", Fournal of Operations Management, Vol. 30 No. 1-2, pp. 55-68.

Harkness, J. (2003), “Questionnaire translation”, In: CrossCultural Survey Methods, Harkness, J.A., van de Vijver, F. and Mohler, P. Ph. (Eds), John Wiley and Sons, New York, NY, 35-56.

Henderson, D., Sheetz, S.D. and Trinkle, B. (2012), "The determinants of inter-organizational and internal in-house adoption of XBRL: a structural equation model", International fournal of Accounting Information Systems, Vol. 13 No. 2, pp. 109-140.

Heras-Saizarbitoria, I., Landín, G. and Molina-Azorín, J. (2011), "Do drivers matter for the benefits of ISO 14001?", International Fournal of Operations \& Production Management, Vol. 31 No. 2, pp. 192-216.

Hillebrand, B., Nijholt, J. and Nijssen, E. (2011), "Exploring CRM effectiveness: an institutional theory perspective", Fournal of the Academy of Marketing Science, Vol. 39 No. 4, pp. 592-608.

Hirschinger, M., Spickermann, A., Hartmann, E., von der Gracht, H. and Darkow, I. (2016), "The future of logistics in emerging markets-fuzzy clustering scenarios grounded in institutional and factor-market rivalry theory", fournal of Supply Chain Management, Vol. 51 No. 4, pp. 73-93.

Hoejmose, S., Grosvold, J. and Millington, A. (2014), "The effect of institutional pressure on cooperative and coercive 'green' supply chain practices", fournal of Purchasing and Supply Management, Vol. 20 No. 4, pp. 215-224.

Honig, B. and Karlsson, T. (2004), "Institutional forces and the written business plan", fournal of Management, Vol. 30 No. 1, pp. 29-48.

Hsu, P., Hu, P., Wei, C. and Huang, J. (2014), "Green purchasing by MNC subsidiaries: the role of local tailoring in the presence of institutional duality", Decision Sciences, Vol. 45 No. 4, pp. 647-682.

$\mathrm{Hu}$, L. and Bentler, P. (1999), "Cutoff criteria for fit indexes in covariance structure analysis: conventional criteria versus new alternatives", Structural Equation Modeling: A Multidisciplinary fournal, Vol. 6 No. 1, pp. 1-55.

Huang, Y.C., Yang, M.L. and Wong, Y.J. (2016), "Institutional pressures, resources commitment, and returns 
management. Supply chain management", An International Fournal, Vol. 21 No. 3, pp. 398-416.

Jin, D., Chai, K.H. and Tan, K.C. (2012), "Organizational adoption of new service development tools", Managing Service Quality: An International fournal, Vol. 22 No. 3, pp. 233-259.

Jöreskog, K. (1967), “A general approach to confirmatory maximum likelihood factor analysis", Psychometrika, Vol. 2, pp. 183-202.

Kauppi, K. (2013), "Extending the use of institutional theory in operations and supply management research - review and research proposals", International fournal of Operations $\mathcal{E}$ Production Management, Vol. 33 No. 10, pp. 1318-1345.

Kauppi, K. and Hannibal, C. (2017), "Institutional pressures and sustainability assessment in supply chains", Supply Chain Management: An International fournal, Vol. 22 No. 5, pp. 458-472.

Kauppi, K. and Van Raaij, E. (2015), "Opportunism and honest incompetence - seeking explanations for noncompliance in public procurement", Fournal of Public Administration Research and Theory, Vol. 25 No. 3, pp. 953-979.

Ke, W., Liu, H., Wei, K.K., Gu, J. and Chen, H. (2009), "How do mediated and non-mediated power affect electronic supply chain management system adoption? The mediating effects of trust and institutional pressures”, Decision Support Systems, Vol. 46 No. 4, pp. 839-851.

Kenny, D., Kaniskan, B. and McCoach, D. (2015), "The performance of RMSEA in models with small degrees of freedom", Sociological Methods E Research, Vol. 44 No. 3, pp. 486-507.

Ketokivi, M.A. and Schroeder, R.G. (2004), "Strategic, structural contingency and institutional explanations in the adoption of innovative manufacturing practices", Fournal of Operations Management, Vol. 22 No. 1, pp. 63-89.

Khalifa, M. and Davison, M. (2006), "SME adoption of IT: the case of electronic trading systems. Engineering management", IEEE Transactions on, Vol. 53 No. 2, pp. 275-284.

Kostova, T. and Roth, K. (2002), "Adoption of an organizational practice by subsidiaries of multinational corporations: institutional and relational effects", The Academy of Management Fournal, Vol. 45 No. 1, pp. 215-233.

Lawrence, T.B., Suddaby, R. and Leca, B. (2011), "Institutional work: refocusing institutional studies of organizations", fournal of Management Inquiry, Vol. 20 No. 1, pp. 52-58.

Li, Y., Ye, F., Dai, J., Zhao, X. and Sheu, C. (2019), "The adoption of green practices by chinese firms", International fournal of Operations \& Production Management, Vol. 39 No. 4, pp. 550-572.

Liang, H., Saraf, N., Hu, Q. and Xue, Y. (2007), “Assimilation of enterprise systems: the effect of institutional pressures and the mediating role of top management”, MIS Quarterly, Vol. 31 No. 1, pp. 59-87.

Lindell, M. and Whitney, D. (2001), “Accounting for common method variance in cross-sectional research designs", fournal of Applied Psychology, Vol. 86 No. 1, pp. 114-121.

Liu, H., Ke, W., Wei, K., Gu, J. and Chen, H. (2010), "The role of institutional pressures and organizational culture in the firm's intention to adopt internet-enabled supply chain management systems", fournal of Operations Management, Vol. 28 No. 5, pp. 372-384.

Lo, S.M. and Shiah, Y.A. (2016), "Associating the motivation with the practices of firms going green: the moderator role of environmental uncertainty", Supply Chain Management: An International fournal, Vol. 21 No. 4, pp. 485-498.

Mani, V. and Gunasekaran, A. (2018), "Four forces of supply chain social sustainability adoption in emerging economies", International fournal of Production Economics, Vol. 199, pp. 150-161.

Martínez-Costa, M., Martínez-Lorente, A. and Choi, T. (2008), "Simultaneous consideration of TQM and ISO 9000 on performance and motivation: an empirical study of Spanish companies", International fournal of Production Economics, Vol. 113 No. 1, pp. 23-39.

Meixell, M.J. and Luoma, P. (2015), "Stakeholder pressure in sustainable supply chain management: a systematic review", International fournal of Physical Distribution \& Logistics Management, Vol. 45 Nos 1/2, pp. 69-89.

Menor, L. and Roth, A. (2007), "New service development competence in retail banking: construct development and measurement validation", fournal of Operations Management, Vol. 25 No. 4, pp. 825-846.

Meyer, J. and Rowan, B. (1977), "Institutionalized organizations: formal structure as myth and ceremony", American fournal of Sociology, Vol. 83 No. 2, pp. 340-363.

Miemczyk, J. (2008), "An exploration of institutional constraints on developing end-of-life product recovery capabilities", International fournal of Production Economics, Vol. 115 No. 2, pp. 272-282.

Mizruchi, M. and Fein, L. (1999), "The social construction of organizational knowledge: a study of the uses of coercive, mimetic, and normative isomorphism", Administrative Science Quarterly, Vol. 44 No. 4, pp. 653-683.

Moore, G. and Benbasat, I. (1991), "Development of an instrument to measure the perceptions of adopting an information technology innovation", Information Systems Research, Vol. 2 No. 3, pp. 192-222.

Moxham, C. and Kauppi, K. (2014), "Using organisational theories to further our understanding of socially sustainable supply chains", Supply Chain Management: An International Fournal, Vol. 19 No. 4, pp. 413-420.

Nair, A. and Prajogo, D. (2009), "Internalisation of ISO 9000 standards: the antecedent role of functionalist and institutionalist drivers and performance implications", International Fournal of Production Research, Vol. 47 No. 16, pp. 4545-4568.

Obayi, R. and Ebrahimi, S.N. (2021), "A neo-institutional view of the transaction cost drivers of construction supply chain risk management", Supply Chain Management: An International fournal, Vol. 26 No. 5.

Pasamar, S. and Alegre, J. (2015), “Adoption and use of worklife initiatives: looking at the influence of institutional pressures and gender", European Management fournal, Vol. 33 No. 3, pp. 214-224.

Peters, P. and Heusinkveld, S. (2010), "Institutional explanations for managers' attitudes towards telehomeworking", Human Relations, Vol. 63 No. 1, pp. 107-135. 
Podsakoff, P., MacKenzie, S., Lee, J.-Y. and Podsakoff, N. (2003), "Common method biases in behavioral research: a critical review of the literature and recommended remedies", Fournal of Applied Psychology, Vol. 88 No. 5, pp. 879-903.

Prajogo, D. (2011), "The roles of firms' motives in affecting the outcomes of ISO 9000 adoption", International fournal of Operations \& Production Management, Vol. 31 No. 1, pp. 78-100.

Pullman, M., Longoni, A. and Luzzini, D. (2018), "The roles of institutional complexity and hybridity in social impact supply chain management", Fournal of Supply Chain Management, Vol. 54 No. 2.

Ramus, T., Vaccaro, A. and Brusoni, S. (2017), "Institutional complexity in turbulent times: formalization, collaboration, and the emergence of blended logics", Academy of Management fournal, Vol. 60 No. 4, pp. 1253-1284.

Rosenzweig, E. and Roth, A. (2007), "B2B seller competence: construct development and measurement using a supply chain strategy lens", fournal of Operations Management, Vol. 25 No. 6, pp. 1311-1331.

Roth, A., Schroeder, R., Huang, X. and Kristal, M. (2008), Handbook of Metrics for Research in Operations ManagementMulti-Item Measurement Scales and Objective Items, Sage Publications, Thousand Oaks, p. 764.

Schoenherr, T. and Swink, M. (2012), "Revisiting the arcs of integration: cross-validations and extensions", fournal of Operations Management, Vol. 30 Nos 1/2, pp. 99-115.

Scott, W. (1987), "The adolescence of institutional theory", Administrative Science Quarterly, Vol. 32 No. 4, pp. 493-511.

Scott, W. (2008), "Approaching adulthood: the maturing of institutional theory", Theory and Society, Vol. 37 No. 5, pp. 427-442.

Shafiq, A., Klassen, R.D., Johnson, P.F. and Awaysheh, A. (2014), "Socially responsible practices: an exploratory study on scale development using stakeholder theory", Decision Sciences, Vol. 45 No. 4, pp. 683-716.

Shi, W., Shambare, N. and Wang, J. (2008), "The adoption of internet banking: an institutional theory perspective", Fournal of Financial Services Marketing, Vol. 12 No. 4, pp. 272-286.

Son, J.Y. and Benbasat, I. (2007), “Organizational buyers' adoption and use of B2B electronic marketplaces: efficiencyand legitimacy-oriented perspectives", fournal of Management Information Systems, Vol. 24 No. 1, pp. 55-99.

Song, L., Song, M. and Di Benedetto, A. (2011), "Resources, supplier investment, product launch advantages, and first product performance", fournal of Operations Management, Vol. 29 Nos 1/2, pp. 86-104.

St John, C., Cannon, A. and Pouder, R. (2001), "Change drivers in the new millennium: implications for manufacturing strategy research", fournal of Operations Management, Vol. 19 No. 2, pp. 143-160.

Stratman, J. and Roth, A. (2002), "Enterprise resource planning (ERP) competence constructs: two-stage multiitem scale development and validation", Decision Sciences, Vol. 33 No. 4, pp. 601-628.

Tachizawa, E.M., Gimenez, C. and Sierra, V. (2015), "Green supply chain management approaches: drivers and performance implications", International fournal of
Operations \& Production Management, Vol. 35 No. 11, pp. 1546-1566.

Tate, W.L., Dooley, K.J. and Ellram, L.M. (2011), "Transaction cost and institutional drivers of supplier adoption of environmental practices", Fournal of Business Logistics, Vol. 32 No. 1, pp. 6-16.

Tate, W.L., Ellram, L.M. and Dooley, K. (2014), "The impact of transaction costs and institutional pressure on supplier environmental practices", International fournal of Physical Distribution \& Logistics Management, Vol. 44 No. 5, pp. 353-372.

Teo, H.H., Wei, K.K. and Benbasat, I. (2003), "Predicting intention to adopt interorganizational linkages: an institutional perspective”, MIS Quarterly, Vol. 27 No. 1, pp. 19-49.

Ugrin, J. (2009), "The effect of system characteristics, stage of adoption, and experience on institutional explanations for ERP systems choice", Accounting Horizons, Vol. 23 No. 4, pp. 365-389.

Venkatesh, V.G., Zhang, A., Deakins, E. and Mani, V. (2020), "Drivers of Sub-supplier social sustainability compliance: an emerging economy perspective", Supply Chain Management: An International foumal, Vol. 25 No. 6, pp. 655-677.

Villena, V.H. and Dhanorkar, S. (2020), "How institutional pressures and managerial incentives elicit carbon transparency in global supply chains”, fournal of Operations Management, Vol. 66 No. 6, pp. 697-734.

Wang, S., Li, J., Song, J., Li, Y. and Sherk, M. (2018), "Institutional pressures and product modularity: do supply chain coordination and functional coordination matter?", International fournal of Production Research, Vol. 56 No. 20, pp. 6644-6657.

Westphal, J., Gulati, R. and Shortell, S. (1997), "Customization or conformity? An institutional and network perspective on the content and consequences of TQM adoption", Administrative Science Quarterly, Vol. 42 No. 2, pp. 366-394.

Yang, C.S. (2017), “An analysis of institutional pressures, green supply chain management, and green performance in the container shipping context", Transportation Research Part D: Transport and Environment, Vol. 61.

Yang, Z. and Su, C. (2014), "Institutional theory in business marketing: a conceptual framework and future directions", Industrial Marketing Management, Vol. 43 No. 5, pp. 721-725.

Zailani, S., Eltayeb, T., Hsu, C. and Tan, K. (2012), "The impact of external institutional drivers and internal strategy on environmental performance", International fournal of Operations \& Production Management, Vol. 32 No. 6, pp. 721-745.

Zhang, D., Linderman, K. and Schroeder, R.G. (2014), "Customizing quality management practices: a conceptual and measurement framework", Decision Sciences, Vol. 45 No. 1, pp. 81-114.

Zhang, C., Viswanathan, S. and Henke, J. (2011), "The boundary spanning capabilities of purchasing agents in buyer-supplier trust development", Fournal of Operations Management, Vol. 29 No. 4, pp. 318-328.

Zhu, Q. and Sarkis, J. (2007), "The moderating effects of institutional pressures on emergent green supply chain 
practices and performance", International fournal of Production Research, Vol. 45 No. 18-19, pp. 4333-4356.

Zhu, Q., Sarkis, J. and Lai, K. (2008), "Confirmation of a measurement model for green supply chain management practices implementation", International Fournal of Production Economics, Vol. 111 No. 2, pp. 261-273.

Zhu, Q., Sarkis, J. and Lai, K. (2013), "Institutional-based antecedents and performance outcomes of internal and external green supply chain management practices", fournal of Purchasing and Supply Management, Vol. 19 No. 2, pp. 106-117.

Zorn, T., Flanagin, A. and Shoham, M. (2011), "Institutional and noninstitutional influences on information and communication technology adoption and use among nonprofit organizations", Human Communication Research, Vol. 37 No. 1, pp. 1-33.

Zsidisin, G., Melnyk, S. and Ragatz, G. (2005), "An institutional theory perspective of business continuity planning for purchasing and supply management”, International Fournal of Production Research, Vol. 43 No. 16, pp. 3401-3420.

\section{Further reading}

Tate, W., Ellram, L. and Kirchoff, J. (2010), "Corporate social responsibility reports: a thematic analysis related to supply chain management", fournal of Supply Chain Management, Vol. 46 No. 1, pp. 19-44. 


\section{Appendix 1}

Table A1 Examples of measures used in past research

\begin{tabular}{|c|c|}
\hline Authors & $\begin{array}{l}\text { Coercive pressure } \\
\text { measurement }\end{array}$ \\
\hline $\begin{array}{l}\text { Kostova and } \\
\text { Roth, } 2002\end{array}$ & $\begin{array}{l}\text { High quality standards in this } \\
\text { country are mandated by law } \\
\text { In this country, laws and rules } \\
\text { in business are strictly enforce } \\
\text { There are laws in this country } \\
\text { to protect consumers } \\
\text { from poor quality } \\
\text { There is a large number of } \\
\text { regulatory bodies in this } \\
\text { country which promote and } \\
\text { enforce quality }\end{array}$ \\
\hline
\end{tabular}

Teo et al. (2003) With regard to my main suppliers that have adopted FEDI. . .

...my firm's well-being depends on their resources. ...my firm cannot easily switch away from them.

...my firm MUST maintain good relationships with them.

... they are the core suppliers in a concentrated industry. With regard to my main customers that have adopted FEDI. .

...my firm's well-being depends on their purchases ... my firm cannot introduce switching costs to them ... my firm MUST maintain good relationships with them ... they are the largest customers in the industry Has your parent company adopted FEDI?

Khalifa and Davison, 2006

Liang et al. (2007)

$\begin{array}{ll}\begin{array}{l}\text { Mimetic pressure } \\ \text { measurement }\end{array} & \begin{array}{l}\text { Normative pressure } \\ \text { measurement }\end{array}\end{array}$

Most of the successful companies in this part of the world are implementing special quality programs like Crosby, Deming, TQM, etc. People in this country know a great deal about quality. There is a lot of talk about quality going on in the media in this country.

There is a very strong message in companies in this country that you can't stay in business nowadays if you do not adopt a total quality philosophy.

What is the extent of FED adoption by your Finn's competitors currently? My main competitors that have adopted FEDI. . .

... have benefited greatly ... are perceived favorably by others in the same industry ... are perceived favorably by suppliers ... are perceived favorably by customers

Competitors that have adopted ETS benefited greatly. Competitors that have adopted ETS are perceived favourably by customers.

Competitors that have adopted ETS are more competitive Our main competitors who have adopted ERP have greatly benefitted

Our main competitors who have adopted ERP are

Doing quality work is at the

heart of who we are as a

people.

In this environment, ensuring

product quality is a moral

obligation.

It is expected in this country that companies would do only high quality work.

People in this country care a

great deal about the quality of their work.

Always do your best.

Companies would do quality

work even if not required by

customers

What is the extent of FEDI

adoption by your firm's

suppliers currently?

What is the extent of FEDI

adoption by your firm's

customers currently?

Do you participate in any

industry, trade or professional bodies where you have been exposed to FEDI promotion and information?

\section{Comments}

Measures tied to particular practice

Measures tied to particular practice
Our employees believe that we should use ETS.

Our employees believe that ETS are the norm in our industry.

Our employees believe that using ETS is beneficial to them

The extent of ERP adoption by your firm's suppliers The extent of ERP adoption by your firm's customers The extent to which the
Measures tied to particular practice

Measures tied to particular practice. Normative measure actually reflects isomorphism (the outcome) 


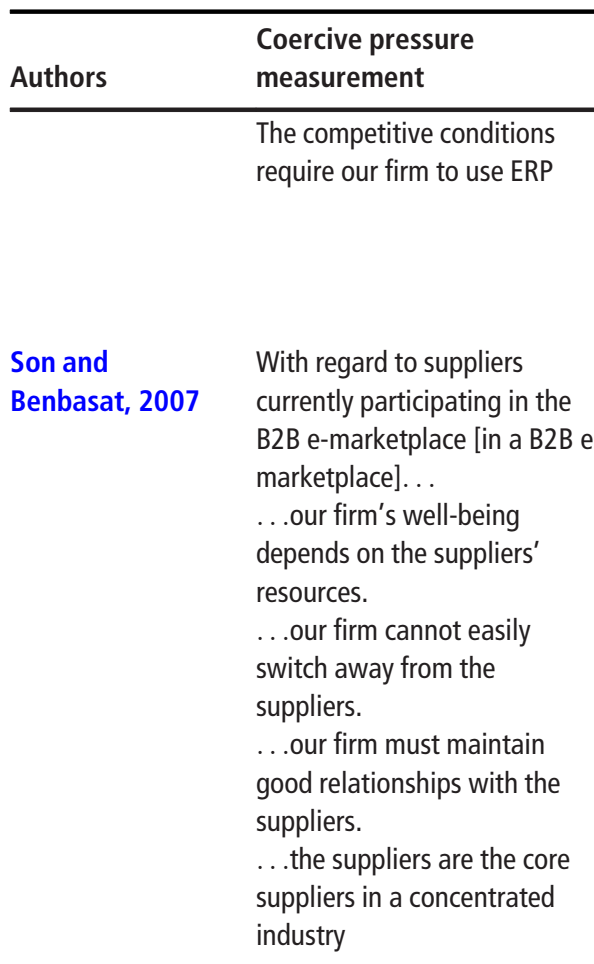

Cheng and $\mathrm{Yu}$, 2008

Shi et al. (2008)

Ke et al. (2009) Our main customers that matter to us believe that we

We may not retain our important customers without eSCMS.

Our customers that are crucial to us encourage us to use eSCMS.

pressures from potential customers pressures from stockholders

Many of my financing tasks requires me to use IB Many transactions can be IB

My financial interactions with my company, friends, and use IB should use eSCMS.

\begin{tabular}{ll}
$\begin{array}{l}\text { Mimetic pressure } \\
\text { measurement }\end{array}$ & $\begin{array}{l}\text { Normative pressure } \\
\text { measurement }\end{array}$ \\
\hline $\begin{array}{l}\text { favorably perceived by others } \\
\text { in the same industry }\end{array}$ & $\begin{array}{l}\text { Government's promotion of } \\
\text { Information Technology }\end{array}$ \\
Our main competitors who & influences your firm to use ERP
\end{tabular}

have adopted ERP are favorably perceived by their suppliers and customers Many of our competitors are currently participating in the B2B e-marketplace [in a B2B emarketplace].

Many of our competitors will be participating in the $\mathrm{B} 2 \mathrm{~B}$ emarketplace [in a B2B emarketplace] in the near future.

Our key competitors are currently participating in the B2B e-marketplace [in a B2B emarketplace].

Our competitors that participate in the $\mathrm{B} 2 \mathrm{~B}$ emarketplace [in a B2B emarketplace]........are benefiting greatly. ... are perceived favorably by others in our industry.

... are perceived favorably by their suppliers

uncertainty in the home country (3 items) imitating successful peers pressure to act in response to competitors other businesses force me to

People around me who use IB have more prestige than those who do not

People around me who use IB have a high profile

Using IB is a status symbol for people around me

Our main competitors that have adopted eSCMS benefited greatly.

Our main competitors that have adopted eSCMS are perceived favorably by customers/suppliers. Our main competitors that
Many of our suppliers are currently participating in the

B2B e-marketplace [in a B2B emarketplace].

Many of our suppliers will be participating in the $\mathrm{B} 2 \mathrm{~B}$ emarketplace [in a B2B emarketplace] in the near future.

Large pressure is placed on our firm to participate in $\mathrm{B} 2 \mathrm{~B}$ emarketplaces by industry sources (e.g., industry or trade associations).

We actively participate in industry, trade, or professional associations that promote participation in B2B emarketplaces.

pressures from the union inter-personal contacts with other CEOs suggestions from board members the CEO's international work experience the CEO's international educational experience I have seen what others do using their IB

Many people in my social network (friends, family, and workmates, classmates) use IB $\mathrm{IB}$ is very visible in my social network (friends, family, and workmates, classmates)

The extent to which eSCMS is adopted by our competitors is high.

The extent to which eSCMS is adopted by our suppliers is high.

The extent to which eSCMS is adopted by our customers is high.

\section{Comments}

Measures tied to particular practice

Item wording not revealed

Measures tied to particular practice.

Measures tied to particular practice. Normative measure actually reflects isomorphism (the outcome) 
Table A1

\begin{tabular}{|c|c|c|c|c|}
\hline Authors & $\begin{array}{l}\text { Coercive pressure } \\
\text { measurement }\end{array}$ & $\begin{array}{l}\text { Mimetic pressure } \\
\text { measurement }\end{array}$ & $\begin{array}{l}\text { Normative pressure } \\
\text { measurement }\end{array}$ & Comments \\
\hline & $\begin{array}{l}\text { Our main suppliers that matter } \\
\text { to us believe that we should } \\
\text { use eSCMS. } \\
\text { Our main suppliers may not } \\
\text { support us if we do not have } \\
\text { eSCMS } \\
\text { Our suppliers that are crucial to } \\
\text { us wish us to use eSCMS }\end{array}$ & $\begin{array}{l}\text { have adopted eSCMS are more } \\
\text { competitive. }\end{array}$ & & \\
\hline Cheng, 2010 & $\begin{array}{l}\text { the robustness of the contract } \\
\text { with the major customer (two } \\
\text { items) } \\
\text { fear of losing the major } \\
\text { customer (two items) } \\
\text { the degree to which the firm } \\
\text { has exceeded the need exerted } \\
\text { by the major customer (two } \\
\text { items) }\end{array}$ & $\begin{array}{l}\text { the need to imitate other peer } \\
\text { suppliers in the same OEM } \\
\text { network (two items) } \\
\text { pressure from key competitors } \\
\text { that serve the same major } \\
\text { clients (two items) } \\
\text { uncertainty regarding OEM } \\
\text { supplier relationships (two } \\
\text { items) }\end{array}$ & & Measures reflect antecedents \\
\hline Liu et al. (2010) & $\begin{array}{l}\text { Our main customers that } \\
\text { matter to us believe that we } \\
\text { should use eSCM. } \\
\text { We may not retain our } \\
\text { important customers without } \\
\text { eSCM. } \\
\text { Our main suppliers that matter } \\
\text { to us believe that we should } \\
\text { use eSCM. } \\
\text { Our suppliers that are crucial to } \\
\text { us hotly wish us to use eSCM }\end{array}$ & $\begin{array}{l}\text { Our main competitors that } \\
\text { have adopted ESCM benefited } \\
\text { greatly. } \\
\text { Our main competitors that } \\
\text { have adopted eSCM are } \\
\text { perceived favorably by } \\
\text { customers. } \\
\text { Our main competitors that } \\
\text { have adopted eSCM are more } \\
\text { competitive }\end{array}$ & $\begin{array}{l}\text { eSCM has been widely adopted } \\
\text { by our suppliers currently. } \\
\text { eSCM has been widely adopted } \\
\text { by our customers currently. } \\
\text { eSCM has been widely adopted } \\
\text { by our competitors currently }\end{array}$ & $\begin{array}{l}\text { Measures tied to particular } \\
\text { practice. Normative measure } \\
\text { actually reflects isomorphism } \\
\text { (the outcome) }\end{array}$ \\
\hline $\begin{array}{l}\text { Hillebrand et al. } \\
\text { (2011) }\end{array}$ & & $\begin{array}{l}\text { Our organization has } \\
\text { implemented CRM in response } \\
\text { to what competitors were and } \\
\text { are doing } \\
\text { Our choice for CRM is clearly } \\
\text { influenced by large attention } \\
\text { for CRM from the management } \\
\text { press and management } \\
\text { consultants. } \\
\text { Our choice to implement CRM } \\
\text { was strongly influenced by } \\
\text { what others in the industry are } \\
\text { doing }\end{array}$ & & $\begin{array}{l}\text { Measures tied to particular } \\
\text { practice }\end{array}$ \\
\hline $\begin{array}{l}\text { Henderson et al. } \\
\text { (2012) }\end{array}$ & $\begin{array}{l}\text { Our trading partners are } \\
\text { pressuring our organization to } \\
\text { use XBRL. }\end{array}$ & $\begin{array}{l}\text { Our organization will use XBRL } \\
\text { to remain competitive. } \\
\text { Approximately what } \\
\text { percentage of the } \\
\text { organizations in your industry } \\
\text { use XBRL? }\end{array}$ & $\begin{array}{l}\text { Our external auditors pressured } \\
\text { our organization to use XBRL. } \\
\text { Third parties, other than XBRL } \\
\text { International or XBRL US (e.g., } \\
\text { AICPA or IMA), that promote } \\
\text { XBRL will influence our } \\
\text { decision to use XBRL. } \\
\text { XBRL International will } \\
\text { influence our decision to use } \\
\text { XBRL. } \\
\text { XBRL US will influence our } \\
\text { decision to use XBRL }\end{array}$ & $\begin{array}{l}\text { Measures tied to particular } \\
\text { practice }\end{array}$ \\
\hline Jin et al. (2012) & $\begin{array}{l}\text { To work with our suppliers, } \\
\text { they require us to use NSD }\end{array}$ & $\begin{array}{l}\text { In your industry, the use of } \\
\text { NSD tools is helpful in allowing }\end{array}$ & & $\begin{array}{l}\text { Measures tied to particular } \\
\text { practice }\end{array}$ \\
\hline
\end{tabular}


Table A1

\begin{tabular}{|c|c|c|c|c|}
\hline Authors & $\begin{array}{l}\text { Coercive pressure } \\
\text { measurement }\end{array}$ & $\begin{array}{l}\text { Mimetic pressure } \\
\text { measurement }\end{array}$ & $\begin{array}{l}\text { Normative pressure } \\
\text { measurement }\end{array}$ & Comments \\
\hline $\begin{array}{l}\text { Zailani et al. } \\
\text { (2012) }\end{array}$ & 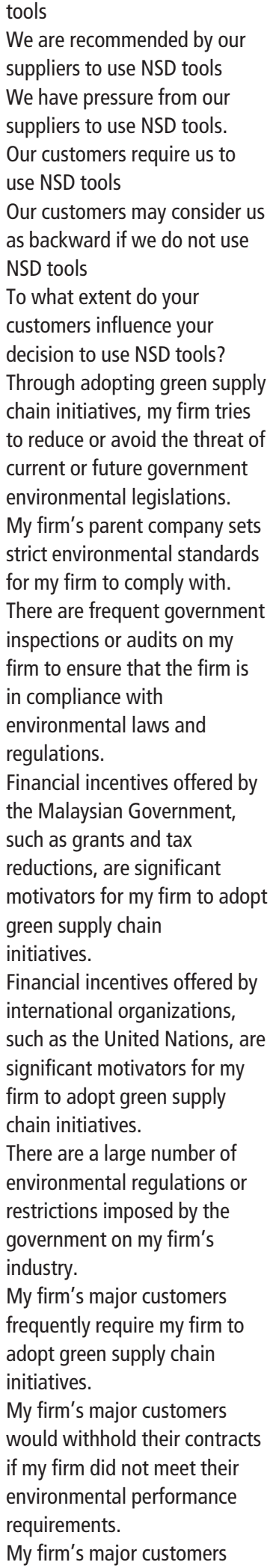 & $\begin{array}{l}\text { a company to remain } \\
\text { competitive } \\
\text { Please indicate the extent of } \\
\text { NSD tool adoption by your } \\
\text { competitors } \\
\text { We are feeling great pressure } \\
\text { to use NSD tools due to our } \\
\text { competitors } \\
\text { Please rate the pressure to } \\
\text { adopt NSD tools placed on } \\
\text { your firm by your competitors }\end{array}$ & & $\begin{array}{l}\text { Measures tied to particular } \\
\text { practice }\end{array}$ \\
\hline
\end{tabular}


Table A1

\begin{tabular}{|c|c|c|c|c|}
\hline Authors & $\begin{array}{l}\text { Coercive pressure } \\
\text { measurement }\end{array}$ & $\begin{array}{l}\text { Mimetic pressure } \\
\text { measurement }\end{array}$ & $\begin{array}{l}\text { Normative pressure } \\
\text { measurement }\end{array}$ & Comments \\
\hline & $\begin{array}{l}\text { have a clear policy statement } \\
\text { regarding its commitment to } \\
\text { the environment. } \\
\text { My firm receives requirements } \\
\text { from consumer associations to } \\
\text { be more environmentally } \\
\text { conscious firm. } \\
\text { My firm's major customers } \\
\text { frequently encourage my firm } \\
\text { to adopt green supply chain } \\
\text { initiatives }\end{array}$ & & & \\
\hline
\end{tabular}




\section{Appendix 2}

Table A2 Item development through four sorting rounds and literature sources for items

\begin{tabular}{|c|c|c|c|c|}
\hline & Supporting literature & ITEM & Decisions & Comments \\
\hline \multirow[t]{15}{*}{ Coercive } & $\begin{array}{l}\text { Mizruchi and Fein, 1999; Shi et al., 2008; Son } \\
\text { and Benbasat, 2007; Teo et al., 2003; Ugrin, } \\
2009\end{array}$ & $\begin{array}{l}\text { Our company's well-being depends on } \\
\text { supplier's resources }\end{array}$ & $\begin{array}{l}\text { Out after 1st } \\
\text { round }\end{array}$ & $\begin{array}{l}\text { Measures dependence, an } \\
\text { antecedent to coercive pressure }\end{array}$ \\
\hline & $\begin{array}{l}\text { Son and Benbasat, 2007; Teo et al., 2003; } \\
\text { Ugrin, 2009; Mizruchi and Fein, } 1999\end{array}$ & $\begin{array}{l}\text { Our firm cannot easily switch away from } \\
\text { current suppliers }\end{array}$ & $\begin{array}{l}\text { Out after 1st } \\
\text { round }\end{array}$ & $\begin{array}{l}\text { Measures dependence, an } \\
\text { antecedent to coercive pressure }\end{array}$ \\
\hline & $\begin{array}{l}\text { Son and Benbasat, 2007; Teo et al., 2003; } \\
\text { Ugrin, 2009; Mizruchi and Fein, } 1999\end{array}$ & $\begin{array}{l}\text { Our main suppliers are the core suppliers } \\
\text { in a concentrated industry }\end{array}$ & $\begin{array}{l}\text { Out after 1st } \\
\text { round }\end{array}$ & $\begin{array}{l}\text { Measures dependence, an } \\
\text { antecedent to coercive pressure }\end{array}$ \\
\hline & $\begin{array}{l}\text { Ke et al., 2009; Jin et al., 2012; Cheng and } \\
\text { Yu, 2008; Henderson et al., 2012; Liu et al., } \\
2010\end{array}$ & $\begin{array}{l}\text { To work with our main suppliers, we } \\
\text { must use certain operating practices }\end{array}$ & $\begin{array}{l}\text { Proceeds to } \\
\text { survey }\end{array}$ & \\
\hline & $\begin{array}{l}\text { Cheng, 2010; Mizruchi and Fein, 1999; Shi } \\
\text { et al., 2008; Teo et al., 2003; Ugrin, } 2009\end{array}$ & $\begin{array}{l}\text { There is a limited and concentrated } \\
\text { customer base for our products/services }\end{array}$ & $\begin{array}{l}\text { Out after 1st } \\
\text { round }\end{array}$ & $\begin{array}{l}\text { Measures dependence, an } \\
\text { antecedent to coercive pressure }\end{array}$ \\
\hline & $\begin{array}{l}\text { Mizruchi and Fein, 1999; Teo et al., 2003; } \\
\text { Ugrin, } 2009\end{array}$ & $\begin{array}{l}\text { Our firm cannot introduce switching } \\
\text { costs to our customers }\end{array}$ & $\begin{array}{l}\text { Out after 1st } \\
\text { round }\end{array}$ & $\begin{array}{l}\text { Measures dependence, an } \\
\text { antecedent to coercive pressure }\end{array}$ \\
\hline & $\begin{array}{l}\text { Braunscheidel et al., 2011; Cheng, 2010; } \\
\text { Cheng and Yu, 2008; Henderson et al., } \\
\text { 2012; Jin et al., 2012; Ke et al., 2009; Nair } \\
\text { and Prajogo, 2009; Zailani et al., } 2012\end{array}$ & $\begin{array}{l}\text { Our main customers frequently make } \\
\text { requests for us to adopt certain practices } \\
\text { or initiatives in our purchasing } \\
\text { procedures }\end{array}$ & $\begin{array}{l}\text { Proceeds to } \\
\text { survey }\end{array}$ & \\
\hline & $\begin{array}{l}\text { Ke et al., 2009; Zailani et al., 2012; Khalifa } \\
\text { and Davison, 2006; Cheng, 2010; Liu et al., } \\
\text { 2010; Shi et al., 2008; Ketokivi and } \\
\text { Schroeder, } 2004\end{array}$ & $\begin{array}{l}\text { Our firms major customers will withhold } \\
\text { their contracts if our firm does not meet } \\
\text { their requests }\end{array}$ & $\begin{array}{l}\text { Proceeds to } \\
\text { survey }\end{array}$ & \\
\hline & $\begin{array}{l}\text { Dasborough and Sue-Chan, 2002; Gopal } \\
\text { and Gao, 2009; Ke et al., 2009; Nair and } \\
\text { Prajogo, 2009; Shi et al., 2008; Zailani } \\
\text { et al., 2012; Zhu and Sarkis, } 2007\end{array}$ & $\begin{array}{l}\text { There are a large number of regulations } \\
\text { and restrictions imposed on my } \\
\text { company's industry that also impact our } \\
\text { purchasing procedures }\end{array}$ & $\begin{array}{l}\text { Proceeds to } \\
\text { survey }\end{array}$ & \\
\hline & $\begin{array}{l}\text { Liang et al., 2007; Shi et al., 2008; Ke } \\
\text { et al., 2009; Zhu and Sarkis, 2007; Ugrin, } \\
2009\end{array}$ & $\begin{array}{l}\text { Government regulation impacts our } \\
\text { purchasing decision making }\end{array}$ & $\begin{array}{l}\text { Proceeds to } \\
\text { survey }\end{array}$ & \\
\hline & Zailani et al., 2012; St John et al., 2001 & $\begin{array}{l}\text { There are frequent government } \\
\text { inspections or audits on our firm to } \\
\text { ensure we comply with laws and } \\
\text { regulations }\end{array}$ & $\begin{array}{l}\text { Proceeds to } \\
\text { survey }\end{array}$ & \\
\hline & Zailani et al., 2012 & $\begin{array}{l}\text { We receive financial incentives from the } \\
\text { government to adopt certain practices in } \\
\text { our purchasing procedures }\end{array}$ & $\begin{array}{l}\text { Out after 1st } \\
\text { round }\end{array}$ & $\begin{array}{l}\text { No consensus, theory does not } \\
\text { specify incentives }\end{array}$ \\
\hline & Teo et al., 2003 & $\begin{array}{l}\text { We must comply with purchasing } \\
\text { procedures set by company } \\
\text { headquarters }\end{array}$ & $\begin{array}{l}\text { Out after 1st } \\
\text { round }\end{array}$ & Seen as internal pressure \\
\hline & $\begin{array}{l}\text { Teo et al., 2003; Shi et al., 2008; Zailani } \\
\text { et al., } 2012\end{array}$ & $\begin{array}{l}\text { Our parent company sets strict } \\
\text { guidelines for purchasing procedures } \\
\text { that we must follow }\end{array}$ & $\begin{array}{l}\text { Proceeds to } \\
\text { survey }\end{array}$ & \\
\hline & $\begin{array}{l}\text { Ke et al., 2009; Heras-Saizarbitoria et al., } \\
\text { 2011; Ugrin, } 2009\end{array}$ & $\begin{array}{l}\text { There exist cultural expectations that } \\
\text { our purchasing procedures must comply } \\
\text { with }\end{array}$ & $\begin{array}{l}\text { Out after 3rd } \\
\text { round }\end{array}$ & \\
\hline \multirow[t]{3}{*}{ Normative } & $\begin{array}{l}\text { Cheng and Yu, 2008; Gopal and Gao, 2009; } \\
\text { Liang et al., } 2007\end{array}$ & $\begin{array}{l}\text { Key employees in our purchasing } \\
\text { function tend to have similar } \\
\text { educational backgrounds }\end{array}$ & $\begin{array}{l}\text { Out after 1st } \\
\text { round }\end{array}$ & Seen as shared background \\
\hline & $\begin{array}{l}\text { Basaglia et al., 2009; Cheng and Yu, 2008; } \\
\text { Gopal and Gao, 2009; Zsidisin et al., } 2005\end{array}$ & $\begin{array}{l}\text { Key employees in our purchasing } \\
\text { function tend to be graduates from same } \\
\text { universities }\end{array}$ & $\begin{array}{l}\text { Out after } 1^{\text {st }} \\
\text { round }\end{array}$ & $\begin{array}{l}\text { Seen as shared background, low } \\
\text { placement ratio }\end{array}$ \\
\hline & Liang et al., 2007 & & $\begin{array}{l}\text { Out after 1st } \\
\text { round }\end{array}$ & $\begin{array}{l}\text { Seen as shared background, low } \\
\text { placement ratio }\end{array}$ \\
\hline
\end{tabular}




\begin{tabular}{l} 
Supporting literature \\
\hline \\
Basaglia et al., 2009; Combs et al., 2009; \\
Gopal and Gao, 2009; Henderson et al., \\
2012; Khalifa and Davison, 2006; \\
Miemczyk, 2008; Teo et al., 2003; Ugrin, \\
2009; Zsidisin et al., 2005 \\
Cheng and Yu, 2008; Gopal and Gao, 2009; \\
Khalifa and Davison, 2006; Zsidisin et al., \\
2005 \\
Gopal and Gao, 2009; Zsidisin et al., 2005; \\
Liang et al., 2007; Combs et al., 2009; \\
Ugrin, 2009 \\
Combs et al., 2009 \\
Teo et al., 2003; Liang et al., 2007; Zhu \\
and Sarkis, 2007, Sila, 2007 \\
Combs et al., 2009; Henderson et al., \\
2012; Hillebrand et al., 2011; Liang et al., \\
and Sarkis, 2007 \\
2007; Teo et al., 2003 \\
Ke et al., 2009; Miemczyk, 2008 \\
\end{tabular}

Mimetic Hillebrand et al., 2011; Khalifa and Davison, 2006; Son and Benbasat, 2007

Ke et al., 2009; Son and Benbasat, 2007; Teo et al., 2003; Henderson et al., 2012; Khalifa and Davison, 2006; Ketokivi and Schroeder, 2004

Henderson et al., 2012; Ke et al., 2009; Khalifa and Davison, 2006; Liang et al., 2007; Liu et al., 2010; Son and Benbasat, 2007; Teo et al., 2003,

ITEM Decisions Comments

Key employees in our purchasing function tend to have similar career tracks

Many of our purchasing employees belong to a national purchasing association

Our employees regularly attend executive education, post-graduate certificate training or equivalent in the area of purchasing

Most purchasing employees tend to have a certification from a national purchasing association/body or equivalent

We follow trade magazines and academic studies on purchasing to learn about purchasing procedures

We actively participate in trade shows and vendor exhibitions

Out after 1st

Seen as shared background round

It is evident that certain purchasing procedures are becoming a norm within our industry

Supplier expectations on purchasing procedures influence our decision making

Customer expectations on the purchasing procedures we use influence our decision making

Opinions of consulting companies and Out after 2nd

external auditors on the best practices in round purchasing procedures influence our decision making

Our purchasing employees prefer to use procedures and tools they learned through their education

Our purchasing employees are influenced by the procedures and tools advocated by the national purchasing association

Purchasing employees in our industry are trained to use similar purchasing procedures

Our organization has implemented purchasing procedures in response to what competitors/peers were and are doing

We pay attention to the purchasing Removed in practices and tools used and adopted by survey testing our key competitors

We pay attention to the purchasing practices and tools that appear to benefit our peers/competitors
Out after 3rd Seen as shared background

round

Out after 3rd Seen as shared background round

Proceeds to

survey

Proceeds to Reworded

Proceeds to survey

Out after 2 nd

Most sorted as coercive

round

Out after 2nd Most sorted as coercive

round

Proceeds to survey

Proceeds to survey

Proceeds to

Created after 1 st round comments survey

Proceeds to survey

Proceeds to survey
No consensus in sorting, word auditor removed

Created after 1 st round comments

Created after 1 st round comments Created after ist round comments Removed due to survey length

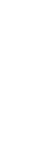




\begin{tabular}{|c|c|c|c|}
\hline Supporting literature & ITEM & Decisions & Comments \\
\hline Cheng, 2010; Khalifa and Davison, 2006 & $\begin{array}{l}\text { There is a need to imitate key } \\
\text { competitors that serve the same major } \\
\text { clients }\end{array}$ & $\begin{array}{l}\text { Proceeds to } \\
\text { survey }\end{array}$ & \\
\hline $\begin{array}{l}\text { Cheng and Yu, 2008; Cheng, 2010; Nair } \\
\text { and Prajogo, } 2009\end{array}$ & $\begin{array}{l}\text { There is a pressure to act in response to } \\
\text { our competitors }\end{array}$ & $\begin{array}{l}\text { Out after 1st } \\
\text { round }\end{array}$ & No consensus \\
\hline $\begin{array}{l}\text { Henderson et al., 2012; Hillebrand et al., } \\
\text { 2011; Jin et al., 2012; Khalifa and Davison, } \\
2006\end{array}$ & $\begin{array}{l}\text { Our choice to implement purchasing } \\
\text { procedures is influenced by what others } \\
\text { in the industry are doing }\end{array}$ & $\begin{array}{l}\text { Out after } 2 \text { nd } \\
\text { round }\end{array}$ & \\
\hline $\begin{array}{l}\text { Ketokivi and Schroeder, 2004; St John } \\
\text { et al., 2001; Zhu and Sarkis, 2007; Zsidisin } \\
\text { et al., } 2005\end{array}$ & $\begin{array}{l}\text { We actively benchmark the purchasing } \\
\text { practices and performance of our main } \\
\text { peers/competitors }\end{array}$ & $\begin{array}{l}\text { Proceeds to } \\
\text { survey }\end{array}$ & \\
\hline \multirow[t]{2}{*}{$\begin{array}{l}\text { Hillebrand et al., 2011; Ketokivi and } \\
\text { Schroeder, 2004; Zsidisin et al., }\end{array}$} & $\begin{array}{l}\text { Our choice to implement purchasing } \\
\text { procedures is influenced by the attention } \\
\text { such practices get in management press } \\
\text { and from management consultants }\end{array}$ & $\begin{array}{l}\text { Out after } 2 \text { nd } \\
\text { round }\end{array}$ & \\
\hline & $\begin{array}{l}\text { Our choice to implement purchasing } \\
\text { procedures is influenced by the attention } \\
\text { such practices get by the national } \\
\text { purchasing association }\end{array}$ & $\begin{array}{l}\text { Out after 2nd } \\
\text { round }\end{array}$ & \\
\hline Dasborough and Sue-Chan, 2002 & $\begin{array}{l}\text { Our choice of consultants is based on } \\
\text { which consultants are competitors/peers } \\
\text { are using }\end{array}$ & $\begin{array}{l}\text { Out after 1st } \\
\text { round }\end{array}$ & Low correct placement ratio \\
\hline Miemczyk, 2008 & $\begin{array}{l}\text { The suitability of purchasing practices in } \\
\text { our industry and operating environment } \\
\text { is uncertain }\end{array}$ & $\begin{array}{l}\text { Out after 1st } \\
\text { round }\end{array}$ & $\begin{array}{l}\text { Measures uncertainty, antecedent } \\
\text { to mimetic pressure }\end{array}$ \\
\hline Cheng, 2010 & $\begin{array}{l}\text { There is high uncertainty regarding our } \\
\text { supplier relationships }\end{array}$ & $\begin{array}{l}\text { Out after 1st } \\
\text { round }\end{array}$ & $\begin{array}{l}\text { Measures uncertainty, antecedent } \\
\text { to mimetic pressure }\end{array}$ \\
\hline \multirow[t]{2}{*}{$\begin{array}{l}\text { Dasborough and Sue-Chan, 2002; } \\
\text { Henderson et al., 2012; Miemczyk, } 2008\end{array}$} & $\begin{array}{l}\text { There is often high uncertainty between } \\
\text { purchasing procedures and tools used } \\
\text { and their impact on performance }\end{array}$ & $\begin{array}{l}\text { Out after 1st } \\
\text { round }\end{array}$ & $\begin{array}{l}\text { Measures uncertainty, antecedent } \\
\text { to mimetic pressure }\end{array}$ \\
\hline & $\begin{array}{l}\text { There is a high amount of employee } \\
\text { turnover in the purchasing functions } \\
\text { within our industry }\end{array}$ & $\begin{array}{l}\text { Out after 1st } \\
\text { round }\end{array}$ & No consensus \\
\hline
\end{tabular}




\section{Appendix 3}

Table A3 Response statistics per country for IPS2 data and for second survey in Italy

\begin{tabular}{|c|c|c|c|c|c|c|}
\hline & Finland & Germany & Ireland & Italy & Total & $\%$ of total sample \\
\hline Sample Size & 832 & 800 & 583 & 853 & 3,068 & \\
\hline Reached via phone & 255 & 338 & 242 & 270 & 1,105 & 36 \\
\hline Agreed to participate & 223 & 120 & 109 & 204 & 656 & 21 \\
\hline Responded & 131 & 77 & 70 & 103 & 381 & 12 \\
\hline Complete responses (>70\%) & 84 & 70 & 52 & 99 & 305 & 10 \\
\hline Complete responses on institutional pressures & 76 & 63 & 50 & 88 & 207 & 7 \\
\hline & $\begin{array}{l}\text { Total } \\
\text { (Italy) }\end{array}$ & \multicolumn{5}{|c|}{$\%$ of total sample } \\
\hline Sample Size & 409 & & & & & \\
\hline Reached via email or LinkedIn message & 377 & \multicolumn{5}{|c|}{92} \\
\hline Responded & 73 & \multicolumn{5}{|c|}{18} \\
\hline Complete responses (>70\%) & 70 & \multicolumn{5}{|c|}{17} \\
\hline
\end{tabular}




\section{Appendix 4}

Table A4 Refined set of items for second q-sorting exercise with practitioners

\begin{tabular}{|c|c|c|c|c|}
\hline & Item & & Details & $\begin{array}{l}\text { Included into } \\
\text { 2nd survey }\end{array}$ \\
\hline \multirow[t]{4}{*}{$\begin{array}{l}\text { Coercive } \\
\text { market }\end{array}$} & $\mathrm{CO1}$ & $\begin{array}{l}\text { To work with our major suppliers, we must use } \\
\text { certain operating practices mandated by them }\end{array}$ & Retained from first survey & YES \\
\hline & $\mathrm{CO} 2$ & $\begin{array}{l}\text { Our major external customers frequently make } \\
\text { requests for us to adopt certain practices or } \\
\text { initiatives in our purchasing procedures }\end{array}$ & Retained from first survey & YES \\
\hline & C07new & $\begin{array}{l}\text { We sometimes have to modify our purchasing } \\
\text { practices in response to consumer preferences }\end{array}$ & $\begin{array}{l}\text { New item to reflect market pressure, } \\
\text { supported by Castka and Balzarova, 2008; } \\
\text { Hoejmose et al., 2014; Meixell and Luoma, } \\
2015\end{array}$ & YES \\
\hline & Co9new & $\begin{array}{l}\text { We sometimes have to modify our purchasing } \\
\text { practices in response to media actions }\end{array}$ & $\begin{array}{l}\text { New item to reflect market pressure, } \\
\text { supported by Tate et al., 2011; } \\
\text { Meixell and Luoma, } 2015\end{array}$ & YES \\
\hline \multirow[t]{3}{*}{$\begin{array}{l}\text { Coercive } \\
\text { regulatory }\end{array}$} & $\mathrm{CO} 4$ & $\begin{array}{l}\text { There are a large number of regulations and } \\
\text { restrictions imposed on my company's industry } \\
\text { that also impact our purchasing procedures }\end{array}$ & Retained from first survey & YES \\
\hline & $\mathrm{CO5}$ & $\begin{array}{l}\text { Government regulation impacts our purchasing } \\
\text { decision making }\end{array}$ & Retained from first survey & YES \\
\hline & $\mathrm{CO6}$ & $\begin{array}{l}\text { There are frequent government inspections or } \\
\text { audits on our company's purchasing practices to } \\
\text { ensure we comply with laws and regulations }\end{array}$ & Retained from first survey & YES \\
\hline \multirow[t]{7}{*}{ Mimetic } & MI1 & $\begin{array}{l}\text { Our company has implemented purchasing } \\
\text { procedures in response to what competitors } \\
\text { and peers do and are doing }\end{array}$ & Retained from first survey & YES \\
\hline & MI2 & $\begin{array}{l}\text { We pay attention to the purchasing practices and } \\
\text { tools that appear to benefit our competitors } \\
\text { and peers }\end{array}$ & Retained from first survey & YES \\
\hline & MI3 & $\begin{array}{l}\text { There is a need to imitate purchasing practices } \\
\text { of key competitors that serve the same } \\
\text { major clients }\end{array}$ & Retained from first survey & YES \\
\hline & MI4 & $\begin{array}{l}\text { We actively benchmark the purchasing practices } \\
\text { and performance of our main competitors } \\
\text { and peers }\end{array}$ & Retained from first survey & YES \\
\hline & MI5new & $\begin{array}{l}\text { We pay attention to the purchasing practices } \\
\text { and tools used and adopted by our key competitors }\end{array}$ & Retained from academic q-sorting & YES \\
\hline & MI6new & $\begin{array}{l}\text { There is a pressure to act in response to our } \\
\text { competitors }\end{array}$ & Retained from academic q-sorting & NO \\
\hline & & & & (continued) \\
\hline
\end{tabular}


Table A4

\begin{tabular}{|c|c|c|c|c|}
\hline & Item & & Details & $\begin{array}{l}\text { Included into } \\
\text { 2nd survey }\end{array}$ \\
\hline & MI7new & $\begin{array}{l}\text { Our choice to implement purchasing procedures } \\
\text { is influenced by what others in the industry are doing }\end{array}$ & Retained from academic q-sorting & NO \\
\hline \multirow[t]{8}{*}{ Normative } & N01 & $\begin{array}{l}\text { Our purchasing employees prefer to use procedures } \\
\text { and tools they learned during their education }\end{array}$ & Retained from first survey & YES \\
\hline & NO2 & $\begin{array}{l}\text { Our purchasing employees are influenced by the } \\
\text { procedures and tools advocated by the national } \\
\text { purchasing association (e.g. ISM - Institute of } \\
\text { Supply Management) }\end{array}$ & Retained from first survey & YES \\
\hline & NO3 & $\begin{array}{l}\text { Purchasing employees in our industry are trained } \\
\text { to use similar purchasing procedures }\end{array}$ & Retained from first survey & YES \\
\hline & NO4 & $\begin{array}{l}\text { We follow academic research on purchasing to } \\
\text { learn about purchasing procedures to implement }\end{array}$ & Retained from first survey & YES \\
\hline & N05 & $\begin{array}{l}\text { Our choice to implement purchasing procedures is } \\
\text { influenced by what we see and hear at trade } \\
\text { shows and vendor exhibitions }\end{array}$ & Retained from first survey & NO \\
\hline & N06 & $\begin{array}{l}\text { It is evident that certain purchasing procedures } \\
\text { are becoming a norm within our industry }\end{array}$ & Retained from first survey & YES \\
\hline & N07new & $\begin{array}{l}\text { Opinions of consulting companies and external } \\
\text { auditors on the best practices in purchasing } \\
\text { procedures influence our procedures }\end{array}$ & Retained from academic q-sorting & YES \\
\hline & No8new & $\begin{array}{l}\text { Non-governmental organizations influence our } \\
\text { purchasing practices }\end{array}$ & $\begin{array}{l}\text { New item to reflect normative pressure, } \\
\text { supported by Moxham and Kauppi, } 2014\end{array}$ & NO \\
\hline
\end{tabular}

\section{Corresponding author}

Katri Kauppi can be contacted at: katri.kauppi@aalto.fi

For instructions on how to order reprints of this article, please visit our website:

www.emeraldgrouppublishing.com/licensing/reprints.htm

Or contact us for further details: permissions@emeraldinsight.com 